Autio Anna (Orcid ID: 0000-0003-0971-7764)

Ala-aho Pertti (Orcid ID: 0000-0002-1855-5405)

\title{
Implications of peat soil conceptualization for groundwater exfiltration in numerical modeling: A study on a hypothetical peatland hillslope
}

\section{A. Autio ${ }^{1}$, P. Ala-Aho ${ }^{1}$, A.-K. Ronkanen ${ }^{1}$, P. M. Rossi ${ }^{1}$, and B. Kløve ${ }^{1}$}

${ }^{1}$ University of Oulu, Faculty of Technology, Water, Energy and Environmental Engineering Research Unit, P.O. Box 4300, FI-90014 University of Oulu, Finland.

Corresponding author: Anna Autio (anna.autio@oulu.fi)

\section{Key Points:}

- Peat soil layer geometry controls spatial pattern and extent of simulated groundwater exfiltration flux

- Landscape slope and porous media hydraulic properties control total groundwater exchange flux magnitude more than peat layer geometry

- Hydrological impact of groundwater drawdown near groundwater-fed peatlands is not captured by monitoring peatland groundwater levels alone

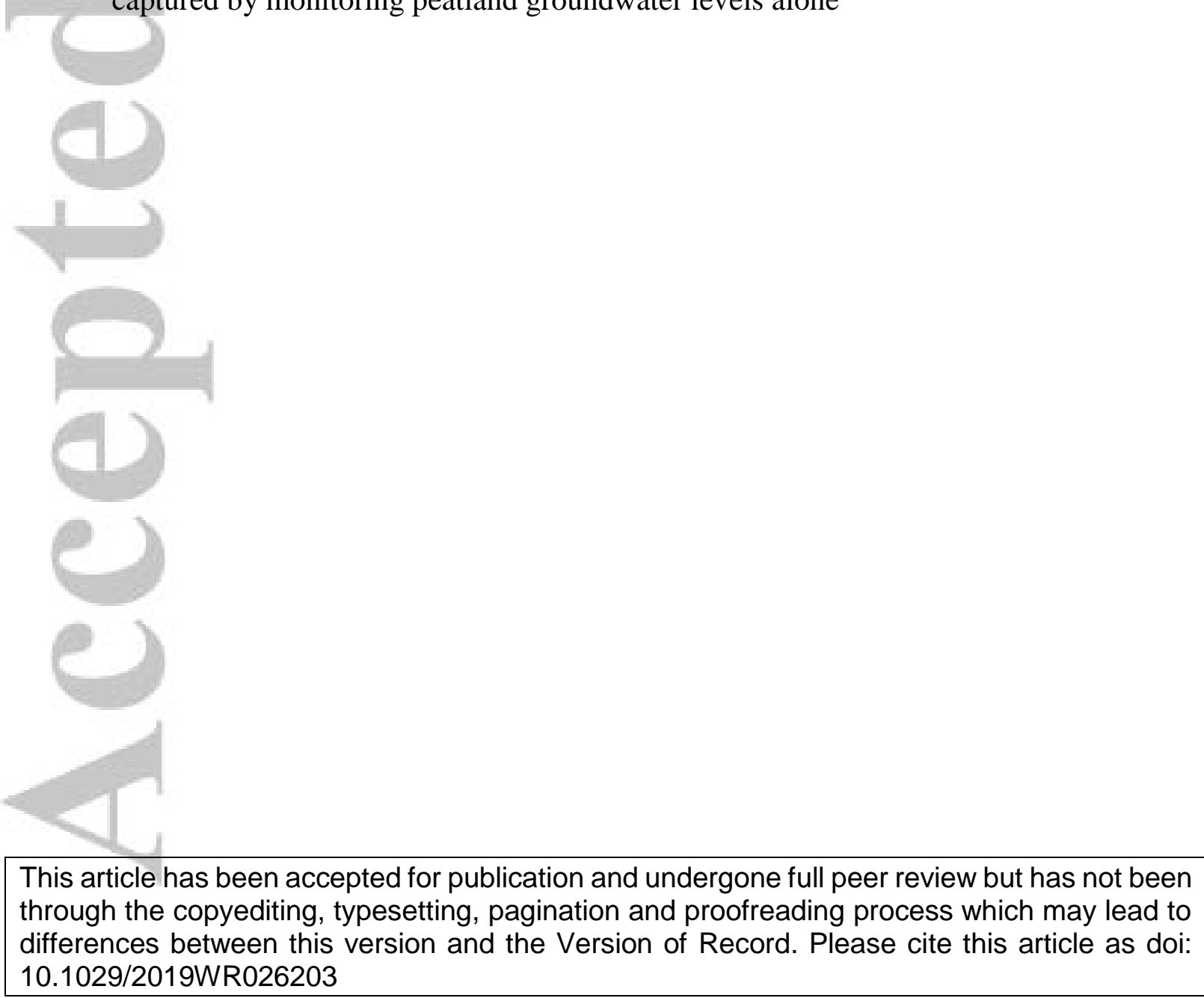




\begin{abstract}
Fully-integrated physically-based hydrological modeling is an essential method for increasing hydrological understanding of groundwater-surface water (GW-SW) interactions in peatlands and for predicting anthropogenic impacts on these unique ecosystems. Modeling studies represent peat soil in a simplistic manner, as a homogeneous layer of uniform thickness, but field measurements consistently show pronounced spatial variability in peatlands. This study evaluated uncertainty in groundwater levels and exfiltration fluxes associated with the simplified representation of the peat soil layer. For transferability of the results, impacts of selected topographical and hydrogeological conceptual models on GW-SW exchange fluxes were simulated in a hypothetical hillslope representing a typical aquifer-mire transect. The results showed that peat soil layer geometry defined the simulated spatial GW-SW exchange patterns and groundwater flow paths, whereas total groundwater exfiltration flux to the hillslope and groundwater level in the peatland were only subtly altered by different conceptual peat soil geometry models. GW-SW interactions were further explored using different scenarios and dimensionless parameters for peat hydraulic conductivity and hillslope-peatland system slope. The results indicated that accurate representation of physical peat soil properties and landscape topography is important when the main objective is to model spatial GW-SW exchange. Groundwater level in virtual peatland was not greatly affected by groundwater drawdown in an adjacent aquifer, but the magnitude and spatial distribution of GW-SW interactions were significantly altered. This means that commonly used groundwater depth observations near peat-mineral soil interfaces and within peatlands may not be a suitable indicator for monitoring the hydrological state of groundwater-dependent peatland ecosystems.
\end{abstract}

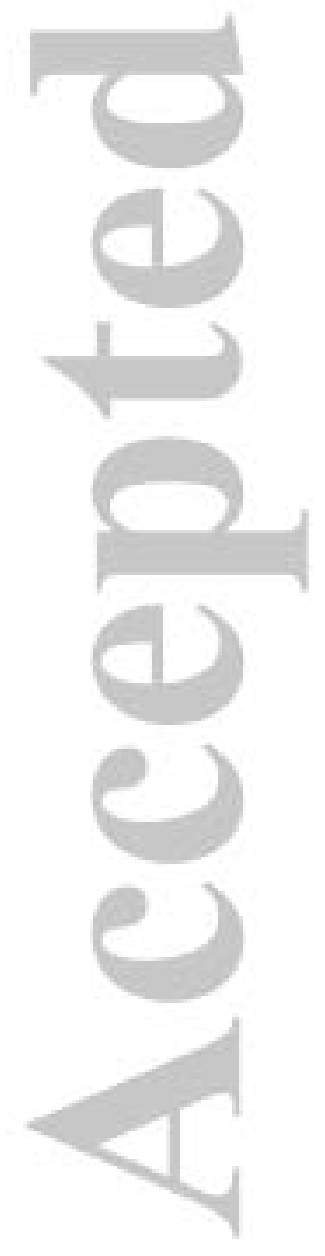




\section{Introduction}

Pristine boreal and subarctic peatlands are highly valued ecosystems due to their unique fauna and the flora and ecosystem services they provide. These peatlands play an important role in global carbon sequestration, storing around one-third of terrestrial carbon (Gorham, 1991; Turunen et al., 2002). Some boreal/subarctic peatlands are sustained by groundwater from glaciofluvial eskers or other glacial soil formations (Isokangas et al., 2017; Nadeau et al., 2015; Rossi et al., 2012; Winter et al., 1998). When groundwater discharges at the surface of a mire (typically named acrotelm), it creates a distinct type of groundwater-surface water (GWSW) interaction sustaining specific groundwater-dependent flora. Despite groundwater flow can being of the main drivers of biogeochemical processes in peatlands, the role of groundwater in peatland water, carbon and nutrient balances is still poorly understood. Filling this knowledge gap requires a better understanding of the dynamics of GW-SW interactions and ability to quantify them with field methods and numerical modeling.

A variety of field techniques are available for i) studying the GW-SW interface, ii) monitoring GW-SW interactions over different scales, and iii) assisting in classification and delineation of groundwater-dependent peatlands. These techniques, applicable for peatland sites, include conventional direct hydrological measurements (use of piezometers, slug tests, boreholes, etc.) (Johansen et al., 2011; Rossi et al., 2012), thermal imaging and other remote sensing techniques (Bechtold et al., 2018; Briggs et al., 2016; Hare et al., 2015, 2017), geophysical measurements (Lowry et al., 2009; McLachlan et al., 2017), and use of natural tracers, including stable water isotopes (Isokangas et al., 2017; Levy et al., 2014, 2016; Négrel et al., 2010). These methods provide valuable information on the current state of GW-SW connectivity, but are of little use in predicting how the system will react to changing conditions, such as groundwater abstraction, changes in land use, or climate change. Current monitoring technology also has limited capability for quantifying GW-SW interactions at large scales, such as catchment or regional scale. Quantifying GW-SW interactions at larger scales may still be necessary to resolve carbon balance and water management questions.

Numerical modeling provides a unique method to study GW-SW interactions at large scales. In the past, groundwater and surface water hydrology were conceptually differentiated and modeled by separate modeling approaches (Barthel, 2014). However, as groundwater and surface water form a continuum, the need for a holistic hydrological approach is now widely recognized (Barthel \& Banzhaf, 2016; Winter et al., 1998). Most recent hydrological modeling applications attempt to include representations of both surface and subsurface domains, but the rigor of physical flow process representation varies between applications. A common approach is to apply so-called 'loosely coupled schemes', in which two or more individual models or model packages are coupled to each other via exchange of results, by using output of one model as input to the other (e.g., Roland Barthel \& Banzhaf, 2016). Fully-integrated physically-based models are a step forward, providing a realistic and physically-based framework to simulate exchange fluxes between groundwater aquifers and groundwater-dependent ecosystems. By creating seamless physically-based descriptions of the whole hydrological cycle, including saturated and unsaturated groundwater flow and surface flow, these models solve numerical equations simultaneously and allow for a continuum of different model components.

This continuum permits systematic description of various hydrological responses and enables dynamic changes in groundwater and surface water processes to be studied. The close GW-SW coupling is essential in the case of groundwater-dependent mires, where the water flux through the peat-mineral soil interface provides information on the availability of possibly nutrient- or mineral-rich groundwater, whichis a prerequisite for typical indicator plant species of groundwater-dependent peatlands that have limited ability to take up water from greater 
depths (Aldous \& Bach, 2014). Although a variety of fully-integrated codes are available, only a few are in common use from which the most popular ones are HydroGeoSphere (Aquanty, 2015), ParFlow (Kollet \& Maxwell, 2006) and OpenGeoSys (Kolditz et al., 2012). Fullyintegrated codes differ in the formulation of governing equations, the coupling between GWSW domains, and spatial and numerical discretization (see e.g., Kollet et al., 2017; Maxwell et al., 2014). They have been utilized to model GW-SW interactions over a range of landscapes and climates (Ala-aho et al., 2015; Chow et al., 2018; Glaser et al., 2016; Gleeson \& Manning, 2008; Jones et al., 2008), including peatlands (Ala-aho et al., 2017; Hwang et al., 2018; Thompson et al., 2015; Thompson et al., 2017).

However, there is no rigorous framework on how to represent peat soils in fullyintegrated GW-SW models. Peat soils have highly heterogeneous properties (Baird et al., 2008; Beckwith et al. 2003; Holden \& Burt, 2003; Isokangas et al. 2017; Lewis et al., 2012, Päivänen, 1973; Rosa \& Larocque, 2008) and are thus difficult to represent in numerical models. Field studies have shown that factors such as preferential flow paths (Holden \& Burt, 2002; Lowry et al., 2009), hydraulic conductivity (Drexler et al., 1999; Hare et al., 2017), and abrupt changes in peat thickness (Hare et al., 2017; Lowry et al., 2009) may affect the location of groundwater discharge. However, most fully-integrated physically-based modeling studies tend to represent the peat domain in a simplified manner, as a constant-depth layer with homogeneous hydraulic properties. An overview of previous fully-integrated physically-based simulations that have included conceptualization of peatlands is provided in Table 1. Use of a simplified representation of peatlands in models is common, even in modeling studies directly focusing on the role of peatlands in local settings (Thompson et al., 2015, 2017), in watershed functioning (Hwang et al., 2018), or as part of a study site landscape (Ala-aho et al., 2015; Smerdon et al., 2007). The effect of simplified treatment of peatland in models is unknown, especially the implications for the magnitude and spatial distribution of fluxes. Therefore, peatland conceptualization should be thoroughly investigated before fully-integrated models are widely used as predictive tools to address the question of how these systems might respond to anthropogenic change. Heterogeneity in the hydraulic properties of peat is difficult to quantify at high spatial resolution (Hare et al., 2017; Holden \& Burt, 2002; Koch et al., 2017; Quillet et al., 2017; Rossi et al., 2012). However, techniques for determining the geometry and bulk hydraulic properties of peat layers using soil cores, in situ hydraulic measurements, or non-invasive geophysical techniques are more readily available, and could be better conceptualized into numerical models.

The aim of the present study was to determine the importance of features of the aquifermire system, such as soil layer geometry and peat soil properties, when simulating GW-SW exchanges. Particular attention was paid to the implications of using the models as predictive tools for assessment of human impacts on groundwater-dependent peatlands. Steady-state conceptual model (CM) simulations of an idealized hypothetical hillslope representing a typical boreal aquifer-mire transect were conducted using the fully-integrated physically-based code HydroGeoSphere. Use of a hypothetical hillslope steady-state model provides several advantages over models of actual field sites. Numerical experiments allow the importance of target factors to be assessed in a transparent manner under a variety of topographical and hydrogeological settings, while a generic simulation set-up and use of dimensionless parameters allow transferability of concepts and results. Specific objectives of this study were to:

- Quantify the effect of peat soil geometry representation in a fully-integrated GW-SW model on the magnitude and spatial distribution of GW-SW exchange fluxes in a hypothetical hillslope transferable to different environments 
- Employ different simulation scenarios and dimensionless variables to study other potential factors controlling the location and magnitude of groundwater discharge, in addition to peat soil geometry

- Apply the generic simulations to examine the vulnerability of the peat-hillslope system to long-term land use influences such as climate change and groundwater level decline due to abstraction.

\section{Methods}

2.1 Conceptual model for the simulated hillslope

In our conceptual model, the interface between a typical boreal groundwater-dependent peatland and mineral deposits is represented by a $1000 \mathrm{~m}$ long two-dimensional (2D) hillslope profile (Fig. 1a). Starting at the maximum topographical height (left boundary of the model), the land elevation decreases linearly towards the peatland area, representing an aquifer. At the peatland, the slope declines to represent the typical peatland flat topography. Consequently, the lowest point is at the right boundary of the model domain (Fig. 1a). The slope varies with the conceptual model type studied (see subsection 2.4). Model parameters need to be defined separately for the subsurface flow domain and overland flow domain for the numerical model application (see subsection 2.2.1). The mineral soil of the subsurface layer, referred to hereafter as the 'mineral soil zone', includes the saturated and unsaturated soil layer covered by forest vegetation. The overland flow domain on the mineral soil is referred to hereafter as 'overland mineral. The overland and subsurface flow domains in the peat are referred to individually as 'overland peat' and 'subsurface peat', and collectively as the 'peat zone'. In the present study, microtopography was represented by overland domain properties, and rill and obstruction storage parameters, with distinct values for each zone (Frei \& Fleckenstein, 2014).

Groundwater-dependent peatlands act as transition zones between groundwater systems and surface water environments. The exact GW-SW interface, i.e., the subsurface region proximal to surface water bodies (McLachlan et al., 2017), can be difficult to define for peatland environments. For this reason, in the present study the GW-SW interface was conceptualized in two different ways. The first conceptualization was the interface between mineral soil and peat soil in the subsurface domain (GW-peat interface; Fig. 1a). The groundwater flux through this interface, i.e., the total amount of groundwater discharging to the peatland (hereafter referred as 'the flux through the bottom of the peat') affects the microbiological activity (Lin et al., 2012; Mitchell \& Branfireun, 2005). However, this flux does not necessarily reach the peat surface and may not be available for peat vegetation. Thus, the boundary between the overland and subsurface domains of the numerical model was considered as another interface (peat-SW interface; Fig.1a).

\subsection{Numerical model implementation}

\subsubsection{HydroGeoSphere}

Numerical modeling was conducted using the fully-integrated physically-based code HydroGeoSphere (Aquanty, 2015). HydroGeoSphere is a control-volume finite-element modeling software that simultaneously solves the Richards equation (Richards, 1931) and 2D diffusion-wave Saint-Venant approximation to represent flow processes in subsurface and overland flow domains, respectively. The implicit simultaneous solution of the governing equations provides a direct representation of feedbacks between the porous domain and surface 
domain, which enables autogenesis of surface water body features; i.e., rivers and lakes are formed in topographical depressions in a physically-based way (Brunner \& Simmons, 2012). These features make the HydroGeoSphere code suitable for modeling GW-SW exchange fluxes. HydroGeoSphere has been successfully applied in studying GW-SW interactions in peat-dominated environments at various scales (e.g., Frei \& Fleckenstein, 2014; Hwang et al., 2018; Liu et al., 2016; Smerdon et al., 2007; C. Thompson et al., 2015). Recent studies by Alaaho et al. $(2015,2017)$ and Glaser et al. (2016) show that, if properly calibrated, the HydroGeoSphere model is also able to reproduce GW-SW exchange patterns in riparian headwaters and lakes. For a detailed description of HydroGeoSphere capabilities, theory, and numerical implementation, see the software manual (Aquanty, 2015).

\subsubsection{Model mesh}

The subsurface model domain was discretized using $1 \mathrm{~m}$ square elements in the horizontal direction and $0.1 \mathrm{~m}$ elements in the vertical direction for the top domain down to 4 $\mathrm{m}$ depth. Elements below $4 \mathrm{~m}$ depth in the model domain varied in vertical thickness, with thickness increasing towards the bottom. In total, the subsurface part of the model comprised 72 vertical layers, 146,146 nodes, and 72,000 elements. For the numerical model solution, the mesh was extended to a third dimension with a unit width of $1 \mathrm{~m}$. During model solution, the blocks were further subdivided into tetrahedral elements, in order to decrease the numerical error related to negative transmissivities (Letniowski \& Forsyth, 1991).

\subsubsection{Boundary conditions and running settings}

Boundary conditions applied to the subsurface model domain consisted of no-flow at the bottom of the model domain and constant head boundary conditions at the right and left edges (Fig. 1a). The no-flow boundary at the bottom portrays relatively impermeable and hydrologically inactive bedrock. The constant head boundary conditions were selected to mimic a peatland-mineral deposit interface cross-section. The constant head boundary condition on the left was equivalent to a depth to groundwater of $10 \mathrm{~m}$. This is within the range typical for boreal shallow groundwater systems (e.g., Okkonen \& Kløve, 2011; Quillet et al., 2017; Rossi et al., 2012). At the right edge of the domain, the constant head was set to equal the land elevation. This boundary condition represents a regional surface water feature such as a river or lake.

Surface water was allowed to freely exit the model by assigning a critical depth boundary condition to the top nodes at the right edge of the model domain. For simplicity, no rainfall (zero flux) boundary conditions were applied to the top of the model. The boundary conditions applied enabled us to study the effects of peat layer geometry and of other system features on GW-SW exchange fluxes without introducing unnecessary complexity. A dual node approach was used for coupling surface and subsurface flow. This method uses first-order leakage relation similar to Darcy flux to describe the exchange flux between domains separated by a thin 'imaginary' layer interface defined by a coupling length $l_{\text {exch }}$, a non-physical parameter estimated to preserve- near-continuity of pressure between the overland and subsurface flow domains (Ebel et al., 2009; Liggett et al., 2012). Coupling length $l_{\text {exch }}=$ $0.001 \mathrm{~m}$ was chosen according to recommendations by Liggett et al. (2012). The parameter value was assessed by conducting sensitivity analysis using values $l_{\text {exch }}=0.01 \mathrm{~m}$ and $l_{\text {exch }}=$ $0.0001 \mathrm{~m}$. In most of the model set-ups tested, model outputs were insensitive to coupling length. The quasi-steady-state solution was accomplished by executing a transient state model and allowing the model to drain over the arbitrary 1000-year period with a variable time step. The steady-state solution was verified by checking rate of change of storage for the entire model domain, which should be approximately 0 . 


\subsection{Conceptual models to study features influencing GW-SW water exchange}

The effects of peat layer geometry and of other system features on GW-SW interactions were evaluated using conceptual model simulations by sequentially changing various model characteristics (Table 2). This included comparing the outputs of models with varying peat soil layer geometries (including a case without a peat layer), soil hydraulic conductivities (peat and mineral soil zones), domain slope, vertical discretization, and boundary conditions. The whole subsurface domain of the reference model consisted of sand soil, but different overland flow properties were assigned to the peat and mineral soil zones (Table 2). The surface properties were the same in all CMs studied.

The effect of peat depth representation was studied by considering three conceptual geometries (CM 1b-d in Table 2). These were: uniform, depth increasing logarithmically, and a realistic geometry soil layer representation based on actual data (hereafter referred to as 'the case study CM') (Fig. 1b). Simulations with peat data from a case study allowed us to compare the influence of increasingly complex peat layer geometries in our hypothetical hillslope. In the case study CM, peat depth distribution was derived from peat thickness data on the Mesisuo-Sarvisuo bog-fen complex in Finland, by extracting peat depth cross-section in the middle part of the peatland from data produced by ground-penetrating radar surveys (Isokangas et al., 2017). The average peat depth of this transect totaled $2.41 \mathrm{~m}$, and peat geometry CMs $1 \mathrm{~b}$ and 1c were built in such a way that their average peat depth was also $2.41 \mathrm{~m}$. The logarithmically increasing peat depth $d$ varied according to the function:

$$
d(x)=p \cdot \log _{10} x
$$

where $p$ is a scaling constant introduced to create a peat depth distribution that results in $2.41 \mathrm{~m}$ average depth of the peat layer (here $p=1.0606$ ) and $x$ represents the distance from the peatland origin.

The effect of the surrounding soil hydraulic properties was tested by simulating all four geometry CMs for sandy soil (CMs 1a-d) and glacial till soil (CMs 2a-d). The subsurface and overland flow domain parameters were defined using literature values and selected to reflect the commonly observed distinctive difference between hillslope and peatland landscape units (Table S1 in Supporting Information). The overland flow domain included 'overland peat' for the 500-1000 m zone and 'overland mineral' for the 0-500 m zone for all peat geometry CMs tested, including the 'no peat' case, in order to exclude the effect of overland properties on flow configuration. For simplification purposes, each soil type was assumed to be isotropic and homogenous. The soil water retention characteristics applied are presented in Fig. S1 in the Supporting Information.

The effect of peat hydraulic conductivity $\left(\mathrm{K}_{\text {peat }}\right)$ on GW-SW exchange flux patterns was investigated in CMs 3a-3d by changing the hydraulic conductivity for the uniform and case study peat soil layer representations by two orders of magnitude. To make the analysis more general and transferable to other landscapes and geologies, a dimensionless parameter ratio of hydraulic conductivity in peat and sand $\left(\mathrm{K}_{\text {peat }} / \mathrm{K}_{\text {sand }}\right)$ was used to study how this ratio controlled the effective exchange fluxes in different peat soil layer geometry CMs. Peat hydraulic conductivity was varied from $1.0 \mathrm{E}-9$ to $1.0 \mathrm{E}-5 \mathrm{~m} / \mathrm{s}$, while sand hydraulic properties were kept constant.

For transferability of the findings to other aquifer-peatland systems, the slopes in the conceptual model simulations were defined to represent typical relief of the boreal landscape. The slopes were determined for esker areas previously studied by Isokangas et al. (2017) and Eskelinen et al. (2015) to represent esker site characteristics, and peatlands in the Pallas area of northern Finland investigated using topographical maps (National Land Survey of Finland, 
2014), to represent fell site characteristics. The sites were chosen to represent contrasting landscape types, i.e., mild relief eskers and steep fell regions present in boreal peatland zones. Slope steepness is a specific hillslope characteristic that usually depends on the distance over which it is evaluated. The calculated slope of esker relief varies between 0 and $3 \%$ for the Rokua esker (Eskelinen et al., 2015), and between $2.5 \%$ and $3.5 \%$ for the Viinivaara aquifer, while peatlands have been found to have slopes of around $0.5 \%$ over the whole length of the peatland. Based on these ranges, it was decided to use a slope of 3\% for the esker area and $0.5 \%$ for the adjacent peat zone. The peatlands in the Pallas area are surrounded by mineral deposits with slope varying between $5 \%$ and $26 \%$, while the slope of the peatlands ranges between $0.2 \%$ and $8 \%$ (National Land Survey of Finland, 2014). Accordingly, it was decided to use a site slope of $10 \%$, as done in a previous study to describe sites of moderate slope (Gleeson \& Manning, 2008), and a slope of $4 \%$ for the peatland zone (CMs 4a-4d). The total thickness of soil deposits was set to be the same as in the mild slope models (CMs 1a-1d).

The general influence of slope steepness on normalized effective exchange fluxes was studied by varying the slope of the mineral soil zone and peat zone. This was done for two peat soil layer geometries in the mild slope set-up. First, the slope of the mineral soil zone was altered from $1 \%$ to $5 \%$ while keeping the peat zone slope constant at $0.5 \%$. Then, the slope of the peat zone was altered from $0.3 \%$ to $1.5 \%$ while the slope of the mineral soil zone was kept constant at 3\%. The changes in normalized effective exchange fluxes are reported with dimensionless ratios between the slopes in the two scenarios.

Vertical and horizontal discretization of the model mesh was expected to have an effect on peat geometry implementation in the model, due to the way in which the mesh was built, and thus to affect the model outputs. The effect of horizontal discretization on model accuracy is a well-recognized issue. Previous studies have shown that horizontal discretization has a larger impact on model results than aggregation of soil hydraulic properties (Sciuto \& Diekkrüger, 2010), due to poor representation of the surface water network in coarser meshes and smoothing of surface slopes (Sciuto \& Diekkrüger, 2010; Wildemeersch et al., 2014). Recalibration of the model may partly compensate for errors related to grid coarsening (Refsgaard, 1997; Wildemeersch et al., 2014). The effect of model vertical discretization has been given little consideration, and then mainly in respect of numerical challenges in accurate solution of the Richards equation (Downer \& Ogden, 2004; Vogel \& Ippisch, 2008). It has also been recognized that vertical discretization of the model affects the magnitude of vertical fluxes in the unsaturated zone (Blessent et al., 2017; Carrera-Hernández et al., 2012). Tetrahedral elements tend to create a 'stair-like' boundary between peat and mineral soil for irregular peat geometries. For this reason, sensitivity of the model to discretization was investigated (CMs 5a-e) for the no peat and case study peat soil layer representations by evaluating two cases: i) vertical discretization of $5 \mathrm{~cm}$ (half that in CMs 1a and 1d, and CMs 5a and 5c, for the no peat and case study peat soil representation, respectively); and ii) vertical discretization of $20 \mathrm{~cm}$ (twice that in CMs 1a and 1d, and CMs 5b and 5d, for the no peat and case study peat soil representation, respectively). In addition, the actual peat depths for the case study peat soil geometry representation were investigated by applying proportional layering within the peat layer, which produced layers with variable thickness that exactly matched the geometry of the interpolated ground-penetrating radar data (CM 5e).

Changes in groundwater levels, mimicking climate variability or groundwater abstraction, were investigated for the uniform (CMs 6a-f) and case study peat soil layer representation (CMs 7a-f) by adjusting boundary conditions at the left edge of the model domain. Profile models are not appropriate to simulate three-dimensional (3D) effects such as radial flow to a pumping well (Anderson et al., 2015), but the long-term effects can be investigated by changing the groundwater level configuration of the modeled system. Wet 
conditions were obtained by raising the specified head boundary condition of $0.5 \mathrm{~m}$, while the effect of groundwater pumping was studied by decreasing the specified head by $0.5 \mathrm{~m}$ and $1 \mathrm{~m}$ until no GW-SW exchange flux in the peatlands was observed. This was equivalent to a specified head of $13.5 \mathrm{~m}$.

\section{Results}

\subsection{Effect of peat geometry on groundwater levels and GW-SW interactions}

The peat soil layer geometry representations (CMs 1a-d) had only a slight effect on groundwater levels in the mineral soil zone and no impact on those in the peat zone (Fig. 2a). The groundwater level intersected with the land surface in the mineral soil zone near the peatland edge (494-499 $\mathrm{m}$ from the left model boundary). The groundwater elevations were overall similar for different peat soil layer geometries, with a maximum difference in elevation of $0.09 \mathrm{~m}$ close to the point of groundwater intersection with the land surface. The uniform peat CM (1b) showed the highest groundwater levels. The logarithmically changing and case study peat soil layer geometries (CMs $1 \mathrm{c}$ and $1 \mathrm{~d}$ ) resulted in lower, but very similar, groundwater levels, whereas the model with no peat (CMs 1a) generated the lowest groundwater elevations.

Presence of a peat layer and its geometry affected groundwater flow paths (Fig. 3). In all peat geometry cases (CMs 1a-1d), shallower groundwater discharged at the break in slope, visible as converging streamlines. In contrast, flux through the bottom of the peat was fed by deeper groundwater and the flow paths were controlled by peat geometry. The deepest groundwater passed under the overlying peatland and was removed from the model by the right-hand side boundary condition, without contact with the peat layer.

The peat soil layer geometry CMs (1a-d) produced distinctly different GW-SW exchange flux patterns (Fig. 2b). In the no peat CM (1a), the exfiltration rate decreased faster with increasing distance from the beginning of the peat zone than for the CMs including peat (1b-d), and remained constant but small in magnitude over a large part of the peat zone ( 470 $\mathrm{m})$. The change into the infiltration zone occurred abruptly and infiltration rate reached the highest values at the end of the peatland. In all CMs including peat (CMs $1 \mathrm{~b}-\mathrm{d})$, groundwater started to discharge with low flow rates at 3-6 m before the peat-mineral soil interface in mineral soil, followed by the highest exfiltration rates at the interface, which is coincident with the break in slope. The exfiltration in the peat zone was slower than in the mineral soil zone before the break of slope, and gradually decreased along the slope. However, it was larger than for the no peat model (CM 1 a) and, importantly, occurred over a long distance (305-457 m). At a certain point in the peatland, exchange dynamics changed from exfiltrating to infiltrating. The location of this point differed between the various peat soil layer geometries. The difference was especially apparent for the case study peat soil layer geometry (CM 1d), while uniform peat (CM 1b) and logarithmically changing peat soil layer (CM 1c) geometries resulted in similar GW-SW exchange flux patterns. In the uniform peat and logarithmically changing peat soil layer geometries, GW-SW exchange flux transition from positive to negative values occurred at similar locations from the beginning of the peat zone, at $\sim 450 \mathrm{~m}$ for the uniform (CM 1b) and $\sim 457 \mathrm{~m}$ for the logarithmically changing (CM 1c) soil layer representations. For the case study CM (1c), exchange flux occurred closest to the beginning of the peatland zone $(\sim 305 \mathrm{~m}$ from the start of the peatland).

For the geometries tested (CMs 1a-d), total groundwater flux through the bottom of the peat and the exfiltration component of GW-SW exchange flux in the whole domain were similar overall in all CMs, ranging from $1.05 \mathrm{E}-06$ to $1.16 \mathrm{E}-06 \mathrm{~m}^{3} / \mathrm{s}$ and from $1.13 \mathrm{E}-06$ to $1.16 \mathrm{E}-06 \mathrm{~m}^{3} / \mathrm{s}$, respectively. Numerical results of different CMs are summarized in Table S2 
and presented graphically in Fig. S2 in Supporting Information. The water balance components for various CMs differed in respect of the amount inflowing and outflowing through the boundary conditions (Fig. S2 in Supporting Information). For comparison purposes, the effective exchange fluxes to the overland domain (spatially integrated GW-SW exchange flux over the mineral soil zone and peatland zone) and flux through the bottom of the peat were normalized by dividing these variables by the total influx through the left-hand side boundary condition. The normalized effective exchange flux to the mineral soil and peatland zones varied for each peat layer geometry representation (Fig. 4a, Table S2). The proportion of water discharging through the peat was highest in the logarithmic peat soil layer representation $(\mathrm{CM}$ $1 \mathrm{c}, 74.0 \%$ ), followed by the uniform peat soil geometry (CM 1b, 72.4\%), while it was lowest in the case study peat representation (CM 1d, $71.2 \%)$. In the no peat case (CM 1a), the groundwater inflow to the surface was significantly less $(47.3 \%)$ than in the models with a peat layer in both mineral soil and peat zone.

\subsection{Effect of soil type (glacial till vs sand, slope, peat hydraulic conductivity)}

The infiltration/exfiltration behavior in glacial till soil (CMs 2a-d) and sandy esker soil (CMs 1a-d) in mild slope models was similar in terms of normalized effective exchange flux (Fig. 4a, 4b). The normalized effective exchange flux was on average 3.7\% higher for the peat zone and 2.6\% lower for the mineral soil zone in the glacial till models (CMs 2a-d) than the sand soil models (CMs 1a-d). In terms of absolute values, the effective exchange flux in glacial till soils was $56 \%$ and $65 \%$ lower in the peat and mineral soil zones, respectively (Fig. S2 in Supporting Information).

The change in peat hydraulic conductivity moderately affected the amount of water flowing through the boundary conditions, groundwater elevation (mean change in the mineral soil zone was 1-2 cm), and the amount of flux through the bottom of the peat (absolute maximum change was 4.4\%). For more details, see Table S2 and Figure S2 in the Supporting Information. However, the alternating peat hydraulic conductivity produced different exchange flux patterns for the two geometries investigated, i.e., the uniform peat and case study peat layer geometry representations (Fig. 5). In the lower hydraulic conductivity cases (CM 3a and 3c; Fig. 4d), the normalized effective exchange flux was higher in the mineral soil zone than in the initial models (CMs $1 \mathrm{~b}$ and $1 \mathrm{~d}$ ), whereas the reverse was true for the higher hydraulic conductivity CMs (3b and 3d). A 10-fold decrease in peat hydraulic conductivity led to a decrease in the normalized effective exchange flux of $15 \%$ and $18 \%$ in the peat zone of the uniform and case study peat soil geometry representations, respectively. A 10-fold increase in conductivity produced $10 \%$ and $5 \%$ higher effective exchange flux in the peat zone of the uniform and case study peat soil layer geometries, respectively.

A plot of soil hydraulic conductivity ratios versus effective exchange flux (Fig. 6a) showed that the total normalized effective exchange flux was approximately constant for $\mathrm{K}_{\text {peat }} / \mathrm{K}_{\text {sand }}$ ratios smaller than 0.01 (i.e., when the hydraulic conductivity of peat was two orders of magnitude smaller than the hydraulic conductivity of sand), and decreased for higher $\mathrm{K}_{\text {peat }} / \mathrm{K}_{\text {sand }}$ ratios. In the mineral soil zone, the normalized effective exchange flux was highest for the case with the lowest peat hydraulic conductivity (i.e., the lowest $\mathrm{K}_{\text {peat }} / \mathrm{K}_{\text {sand }}$ ratio), and decreased with increasing $\mathrm{K}_{\text {peat }} / \mathrm{K}_{\text {sand }}$ ratio. The normalized effective exchange flux to the peat zone reaches its highest value when the $\mathrm{K}_{\text {peat }} / \mathrm{K}_{\text {sand }}$ ratio was 0.1 , and decreased with lower and higher ratios.

In the moderate relief models (CMs 4a-d, Fig. 4c), the fluxes through all defined boundary conditions (constant head on the left and right edge of the model domain, critical depth on the right edge) and through the peat-mineral soil interface were approximately one to 
two orders of magnitude higher than the corresponding fluxes in the mild slope models (CMs $1 \mathrm{a}-\mathrm{d})$. The effective exchange flux was on average $625 \%$ higher for the peat zone and $1508 \%$ for the mineral soil zone (see Fig. S2 in Supporting Information). Thus, for all peat geometries, a larger proportion of effective exchange flux occurred already in the mineral soil zone. This large difference in effective exchange fluxes was because the steeper slope models were associated with higher hydraulic gradients. Consequently, more water was transmitted through the model domain (on average $827 \%$ more) and discharged to the surface domain. The proportion of effective exchange flux in the peat zone to effective exchange flux in the whole model was lower in the moderate slope models than in the mild slope models (CMs 1b-d), but followed the same dynamics as in the mild slope models. The proportion of water discharging through peat was highest in the case study peat soil layer geometry representation (54\% of total normalized effective exchange flux), and lowest in the uniform peat representation (31\% of total normalized effective exchange flux).

A general analysis to compare different slopes of the mineral soil and peat zones using Slope $_{\text {peat }} /$ Slope $_{\text {sand }}$ ratios showed that, for most of the ratios tested, the normalized effective exchange fluxes did not change with varying slope of the mineral soil (peat zone slope kept constant at 0.5\%) (Fig 6b). The only exception was the highest Slope $_{\text {peat }} / S_{\text {Slope }}$ sand ratio (0.5) for the uniform soil layer geometry. This case corresponded to a mild mineral soil zone slope of $1 \%$ and resulted in water elevation being equal to the land surface elevation through the whole hillslope. In the uniform peat soil layer geometry case, the peat layer at the edge of the peatland was thicker than in other cases, and forced more groundwater to discharge already in the mineral soil zone, whereas the total normalized effective exchange fluxes remained similar for all varying mineral soil zone slopes. In contrast, the normalized effective exchange fluxes were sensitive to varying peatland slope (mineral zone slope was kept constant at 3\%). The highest normalized effective exchange fluxes to both peat and mineral soil zones occurred for the smallest Slope $_{\text {peat }} /$ Slope $_{\text {sand }}$ ratio (0.1). The normalized effective exchange fluxes for both peat and mineral zones decreased with increasing Slope $_{\text {peat }} /$ Slope $_{\text {sand }}$ ratio (corresponding to a smaller contrast between peat and mineral soil zone slopes) and approached zero approximately for Slope $_{\text {peat }} /$ Slope $_{\text {sand }}$ ratio $=0.4$.

\subsection{Exchange flux sensitivity to vertical discretization}

The choice of discretization had no impact on GW-SW exchange flux for the no peat model (CMs 1a, 5a and 5b in Fig. 7; CMs visible as one line). In the case study peat soil layer geometry representation (CMs $1 \mathrm{~d}$ and $5 \mathrm{c}-\mathrm{e})$, a more sparsely discretized model produced a 'stepwise' effect on the spatial GW-SW exchange flux (Fig. 7) and slightly modified other output variables. For instance, a change in the discretization from $10 \mathrm{~cm}(\mathrm{CM} 1 \mathrm{~d})$ to $5 \mathrm{~cm}(\mathrm{CM}$ $5 \mathrm{c}$ ) for the case study peat soil layer geometry representation increased the normalized effective flux by $4 \%$ in the mineral soil zone and decreased it by $1 \%$ in the peat zone, compared with the original model (CM 1d). For case study CMs (5c-e), the magnitude of the normalized flux through the bottom of the peat and groundwater elevation was only slightly affected, e.g., the maximum groundwater elevation difference from the original CMs (1d) was around $0.05 \mathrm{~m}$ and the maximum change in the normalized flux through the bottom of the peat was around $0.5 \%$ (for more details, see Table S2).

\subsection{Exchange flux sensitivity to changes in aquifer water level}

Long-term groundwater abstraction/wet conditions were represented in the model by changing (decreasing/increasing) steady-head boundary conditions at the left edge of the model to reflect changes in groundwater configuration of the aquifer. A groundwater head increase of $0.5 \mathrm{~m}$ at the left boundary condition (CM $6 \mathrm{a}$ and $7 \mathrm{a}$ ) from the reference $\mathrm{CMs}$ (1b and $1 \mathrm{~d}$ ) led 
to on average a $0.28 \mathrm{~m}$ rise in the groundwater level in the mineral soil zone (first $500 \mathrm{~m}$ of the model domain) for both the case study and uniform peat soil geometry representations. Lowering the boundary condition of $1 \mathrm{~m}$ from the reference CM (1b and $1 \mathrm{~d}$ ) decreased the groundwater level by on average $0.55-0.56 \mathrm{~m}$. In contrast, the groundwater level in the peat zone was little affected by the change in boundary conditions (Table 3). Groundwater elevation in the peatland was equal to the land surface until the boundary condition dropped below a certain threshold (in the model $14.5 \mathrm{~m}$, corresponding to drawdown of $3 \mathrm{~m}$ ). The maximum groundwater level declined in the peatland zone by $0.13 \mathrm{~m}$ for the uniform and $0.16 \mathrm{~m}$ for the study case peat soil layer representations, at a boundary condition of $13.5 \mathrm{~m}$.

In contrast, the effective exchange flux was very sensitive to changes in boundary conditions (Table 3) and a clear transition occurred from high groundwater dependence to a system with no groundwater input (Table 3). Exchange flux in different CMs indicated that the lower constant head boundary conditions mainly reduced the magnitude of groundwater exfiltration in the first $150 \mathrm{~m}$ of the peat zone $(X=500-650 \mathrm{~m})$, which was evident as reduced positive GW-SW exchange flux values at this distance (Fig. 8). Below the threshold, the steady head boundary condition was $14.5 \mathrm{~m}$ in the uniform and $15.5 \mathrm{~m}$ in the case study peat soil layer geometry, corresponding to a groundwater drawdown of $3 \mathrm{~m}$ and $2 \mathrm{~m}$, respectively, and the beginning of the exfiltration zone shifted towards the center of the peatland. Below these threshold values, the overall length of the exfiltration zone diminished with decreasing groundwater elevation in the aquifer, whereas the transition into the infiltration zone occurred at approximately the same location. When the groundwater configuration was deep enough (in the model corresponding to a steady head boundary condition of $13.5 \mathrm{~m}$; CMs $6 \mathrm{~g}$ and $7 \mathrm{f}$ ), no exchange flux occurred in the whole peatland, seen in Fig. 8 as horizontal yellow lines over the x-axis. Similarly, decreasing groundwater levels affected the overall amount of flux through the bottom of the peatland (Table S2 in Supporting Information). A drawdown of $3.5 \mathrm{~m}$ at the left boundary led to a $98 \%$ and $97 \%$ drop in the flux through the bottom of the peat for the uniform (CM 6e) and case study (CM 7e) peat soil layer representations, respectively, in comparison with the reference cases (CMs $1 \mathrm{~b}$ and $1 \mathrm{~d})$.

\section{Discussion}

4.1 Importance of peat soil representation for the location of simulated GW-SW interactions

Hypothetical hillslope simulations of an aquifer-peatland system under a variety of settings helped to identify the key factors influencing simulated GW-SW interactions in groundwater-fed boreal peatlands. The chosen approach of using a hypothetical hillslope setup makes the findings general and the concepts transferable to similar aquifer-peatland systems. The results revealed that the peat soil layer geometry representation (CMs $1 \mathrm{~b}-\mathrm{d})$ had a minor effect on the total magnitude of the exchange fluxes, but it clearly impacted the spatial variability of GW-SW interactions (Fig. 2b). Changes in peat layer geometry affected groundwater flow paths (Fig. 3), despite the groundwater elevation being only slightly affected within the mineral soil zone and totally unaffected in the peat zone (Fig. 2a). These results indicate that simulated effective exchange fluxes are sensitive to how the peat depth is represented. The spatial distribution of groundwater discharge and recharge, and local GWSW flux values, will most probably be incorrect or inaccurate for simplified peat layer representations (such as CMs a and b), if the actual peat soil layer depth varies considerably within modeled systems. Inclusion of a peat soil layer is crucial when a peatland-dominated landscape is modeled. Simplified representation of a landscape in large-scale models in which small peatland areas are omitted can lead to incorrect GW-SW exchange patterns and errors in 
overall magnitude of effective exchange flux within the studied landscape. This is seen as the clear difference in the simulation results for the model with no peat representation (CM 1a) in comparison with different peat soil geometry representations (CMs 1b-d) in terms of GW-SW distribution and normalized effective exchange flux.

Peat layer geometry will have some effect on the proportion of water discharging to the peat and mineral soil zones, by determining how much of the groundwater will discharge in the mineral soil zone and how much will discharge further downslope in the peat zone. According to our results, thick peat deposits located immediately at the aquifer edge favor higher groundwater discharge to the mineral soil zone. This is consistent with findings by Lowry et al. (2009) that the location of the peat-mineral soil interface controls groundwater flow path in mires and that the occurrence of large springs and ponds is related to the break in slope occurring in the peat soil layer.

The hydraulic conductivity of mineral soil had rather a minor impact on the proportions of exchange fluxes in both the peat and mineral soil zones (Fig. $\mathbf{4 b}$ ), but strongly controlled the magnitude of flux through subsurface boundary conditions and thus significantly affected the overall magnitude of GW-SW interactions (Fig. S2). Better conducting mineral soils have the capability to produce higher GW-SW exchange fluxes. In some cases, this may have important implications for modeling GW-SW interactions in peatlands, as reliable measurement of the mineral soil hydraulic conductivity at larger scales is challenging and small-scale features of flow may be misrepresented in the model. In many cases, springs are located in areas that display differences in hydraulic conductivity (Fetter, 2014).

Peat hydraulic conductivity had a clear effect on the magnitude of GW-SW interactions at the peat surface and their spatial variability (Fig. 5 and 6a), whereas the flux through the bottom of the peat was significantly less affected. Higher peat hydraulic conductivity allowed more water to be conducted near-horizontally within the peat layer. This also allowed for more intense exchange between the subsurface and overland domains. In contrast, lower peat hydraulic conductivity forced a larger proportion of groundwater to discharge already in the mineral soil zone, and decreased GW-SW interaction in the peat zone. Thus, GW-SW dynamics are closely related to the hydraulic properties of peat, as suggested in previous studies (Fraser et al., 2001; Waddington \& Roulet, 1997). The impact of a 10-fold decrease in peat hydraulic conductivity on normalized effective exchange flux to the peat and mineral soil zones (CMs 7a and 7d in Fig. 4d) was comparable to the difference between the uniform and case study peat soil layer geometry representations (CMs 1a and 1d in Fig. 4a).

Analysis of hydraulic conductivities using dimensionless parameter ratios revealed that not only the absolute value, but also the contrast between peat and mineral soils is a key factor in understanding the intensity of GW-SW exchange fluxes. Interestingly, the results showed that the peatland exchange fluxes were highest for a $\mathrm{K}_{\text {peat }} / \mathrm{K}_{\text {sand }}$ ratio of around 0.1 (Fig. 6a). Relatively high hydraulic conductivity of peat allowed substantial flows from hillslope to peatland, whereas a sufficient difference in hydraulic conductivity promoted discharge to the mineral soil zone too. Hydraulic conductivities of peat lower than the 0.1 ratio inhibited exchange between surface and subsurface, whereas higher values promoted flow within the peat matrix parallel to the land surface and resulted in lower GW-SW interactions. In the mineral soil zone, low ratios (low peat hydraulic conductivities) correlated with higher groundwater discharge into the mineral soil part of the slope, as lower peat hydraulic conductivity forced a greater proportion of water to be discharged to the mineral soil zone. These findings emphasize that accurate estimates of the hydraulic conductivities of peat and mineral soil and of peat geometry are essential in correctly representing GW-SW exchange fluxes. Using dimensionless ratios instead of absolute values allows transferability to other 
systems and facilitates quantitative site comparison. For $\mathrm{K}_{\text {peat }} / \mathrm{K}_{\text {sand }}$ ratios $\leq 0.1$, low GW-SW exchange is more likely to be limited by low peat permeability, whereas above this ratio the groundwater exfiltration flux to the surface becomes more unlikely due to lateral flow in the peat.

Our results show that the effect of peat soil layer geometry on the proportions of water discharging to the peat and mineral soil zones may be stronger in systems with steep slopes. Land slope also controls the overall magnitude of effective exchange flux, as overall higher hydraulic gradients have the potential to allow more water to be transmitted through the model domain. In addition to slope, water flowing through any natural system would also be constrained by the amount of groundwater recharge, which was not a limiting factor in our simulation setup due to constant head boundary. It has been reported previously that steeper land slope is associated with intensification of local flows (Gleeson \& Manning, 2008; Tóth, 1963). To generalize our simulations to other settings, we analyzed slope ratios of the peat and mineral soil zones. The results suggest that peatlands with relatively flat slope can be expected to have high GW-SW interactions, whereas peatlands located within hillslopes with low contrast between slopes can be expected to have lower GW-SW interactions.

According to our analysis, slope of the mineral soil has a minor influence on effective GW-SW exchange flux. Different representation of peat thickness in the model (uniform vs case study scenarios) was important only with the steepest mineral soil zone slopes tested, if the groundwater level followed mineral soil zone slope (Fig. 6b). In contrast, peat zone slope strongly influenced the amount of groundwater discharging to the mineral and peat zones. A high contrast between the slopes (strong break in slope, low Slope peat $_{\text {/ Slope }}$ sand ratio) favored groundwater discharge in both peat and mineral soil zones, whereas no or small contrast (weak break in slope) promoted subsurface flow and little interaction between the subsurface and surface domains. To transfer the results to other sites, the analysis suggests pronounced GW$\mathrm{SW}$ interactions primarily in peatlands where the peatland slope is flat in comparison with adjacent hillslopes. Eskelinen et al. (2015) used mineral soil slopes using GIS analysis to identify GW-SW interaction hotspots in peatlands, but our results suggest that the analysis could be more informative if extended to account also for peatland slopes.

In comparison with the effect of other variables, model vertical discretization had only weak effects on simulated normalized effective exchange fluxes. This indicates that the model is not very sensitive to vertical resolution when the model domain is sufficiently discretized and does not create large errors in the model water balance. Model discretization may still lead to variations in the fluxes obtained, especially when it affects the hydraulic properties assigned to given elements. For instance, the no peat CMs produced similar exchange flux patterns for the discretization tested, whereas the proportional layering of the case study soil geometry produced $13 \%$ higher and 5\% lower normalized exchange fluxes in the mineral soil and peatland zones, respectively, than in 10-cm layering. The models with coarser discretization tended to produce shallower groundwater levels (Fig. S3 in Supporting Information). Previous studies have shown that the sensitivity of models based on the Richards' equation to vertical discretization is mainly attributable to numerical stability issues (see e.g., review by Farthing \& Ogden, 2017). Higher resolution results in better solution accuracy, but is also associated with longer computing times. This means that the resolution of vertical discretization should be balanced between simulation accuracy and running times (Carrera-Hernández et al., 2012; Downer \& Ogden, 2004). The coarse representation of hydraulic properties provided by a sparser grid may play a more important role for model flux outputs than numerical inaccuracies when the mesh resolution is already high enough and does not result in high water balance errors. 
Another issue is that non-continuous increment at the peat-mineral interface soil created a 'stepwise' effect on the GW-SW exchange fluxes (Fig. 7), which was especially pronounced in the coarser grids. This seemed to be due to the manner in which the mesh was built and the hydraulic properties assigned to peat (only elements with the centroid above the assigned peat depth were chosen to represent peat soil). Thus, the coarser the mesh, the steeper the stepwise changes in hydraulic properties and in the GW-SW exchange fluxes produced. To date, 'stepwise' implementation of peat depth has only been applied when attempting to include changes in peat thickness in simulations (Ala-aho et al., 2017; Hwang et al., 2018). However, our results suggest that vertical discretization producing possibly a smooth peat representation should be implemented for accurate simulation of shallow groundwater processes in peatlanddominated landscapes.

4.2 Peatland vulnerability to long-term influences (groundwater abstraction, climate change)

Groundwater level configuration (enforced here by specifying a boundary condition) was found to have a profound effect on the magnitude and spatial extent of GW-SW exchange (Fig. 8). This finding has immediate management implications, suggesting that fully-integrated GW-SW modeling can be used to estimate changes in the amount of water discharging to peatlands and the resulting alterations in spatial GW-SW exchange patterns.

After a certain level of drawdown, $3.5 \mathrm{~m}$ in our simulations, the exfiltration zone was greatly reduced and a decrease in peatland groundwater levels was observed. This was linked to significantly decreased fluxes through the bottom of the peat and effective exchange fluxes at the peat-SW interface. Although water level changes remained relatively small in the peat zone, the stress imposed on peat vegetation may be severe, as mire flora typically tolerate only relatively small changes in water level (Aldous \& Bach, 2014; Menberu et al., 2016; Tahvanainen, 2011). Over long periods, persistent groundwater level drawdown in peatland could lead to a transition from unique fen mire groundwater-dependent ecosystems to bog-type peatland where groundwater connection is diminished and the ecosystem is dependent on rain. It is important to note that groundwater level is typically the only parameter monitored in field studies, but does not seem to be a sensitive indicator of changes in GW-SW exchange flux.

\subsection{Limitations of our analysis}

Our hypothetical steady-state hillslope simulations provided a simple framework to investigate factors influencing the magnitude and spatial distribution of GW-SW interactions in a transparent manner over a range of hydrological and geological settings. However, the model configuration applied has limitations, especially due to the simple model geometry and the strong steady-head boundary conditions, which significantly influence the hydrological behavior of the system. Constant head boundary condition at the top of the hillslope profile allows limitless supply of water though the boundary, whereas in reality the water supply would be limited by available groundwater recharge. In order to extend our analysis from changes in water abstraction to changes in water availability, specified flux boundary condition would be more suitable to simulate variability in groundwater recharge. In our conceptual model, the overland mineral and peat zones were devoid of specific microtopographic profiles. Smallscale peatland microtopography is known to influence peatland runoff generation (Frei et al., 2010, 2012; Frei \& Fleckenstein, 2014), and consequently GW-SW interactions at the peat surface. However, the influence is on local and small scale flow paths (peatland hummockhollow scale, cm to meter), whereas we studied GW-SW interaction at hillslope scale.

Another limitation of this study is that effects of other important peat soil properties, such as heterogeneous structure of peat, vertical layering of peat soil with lower hydraulic 
conductivity peat at the bottom and higher in top layers (acrotelm/catotelm model), anisotropy, and dual porosity of peat matrix were not investigated. Previous studies have shown that these properties affect the connection between peatlands and aquifers (Hare et al., 2017; Holden \& Burt, 2002; Koch et al., 2017; Quillet et al., 2017; Rossi et al., 2012). As living peat is highly complex and as data representing all peat soil properties are unavailable, the effect of these properties should be thoroughly investigated in future studies to evaluate the impacts of other simplifications.

Finally, data availability continues to be a challenge in modeling GW-SW interaction in aquifer-peatland systems. The overall low sensitivity of groundwater levels in peat soils to the variables investigated here indicates that the current practice of monitoring groundwater levels may not be a sufficient proxy for modeling GW-SW exchange fluxes in peatlands. Highly spatially variable peat properties, small measurement errors in hydraulic head (Post \& von Asmuth, 2013; Rau et al., 2019), and inaccurate numerical solutions add to parameter nonuniqueness and may further complicate distinguishing between probable and impossible simulated flow regimes. In previous studies, the information content of classical observations such as hydraulic head and streamflow discharge has been demonstrated to be insufficient for calibration of complex hydrological models (reviewed by Schilling et al., 2019). It has been proposed that formulation of calibration problems could be improved, and the uncertainty of predictions reduced, by using non-conventional observations such as temperature, exchange fluxes, tracer concentrations, and residence times. However, implementation of such is challenging, as it often requires additional integration processes in flow models (Schilling et al., 2019).

There is also still a lack of reliable, direct, non-invasive methods for measuring spatial GW-SW exchange flux patterns in peatlands, to obtain data for calibration and validation of fully-integrated models. Non-direct measurement techniques for quantifying GW-SW exchange fluxes within peatlands could be used to define informative spatial groundwater discharge patterns for the calibration process. For instance, thermal infrared imagery (Briggs et al., 2016; Hare et al., 2015, 2017; Isokangas et al., 2017), geophysical techniques (McLachlana et al., 2017) and stable water isotopes (Isokangas et al., 2017; Levy et al., 2014, 2016) can be valuable methods for distinguishing between groundwater-dependent and rainfall-fed areas within peatlands in studies seeking qualitative information on GW-SW exchange fluxes. Geophysical techniques in particular can provide valuable information on the variability of hydrogeological properties, e.g., hydraulic conductivity, that play important roles in shaping GW-SW interactions. Further integration of water quality, temperature, geophysical, and remote sensing data will hopefully help resolve parameter identifiability issues.

\section{Conclusions}

Based on numerical simulations in a transferrable hypothetical hillslope, the following conclusions on GW-SW interactions in peatlands can be drawn:

It is important to consider peat soil geometry when modeling spatial GW-SW exchange patterns and groundwater flow paths in peatlands. When studying the extent of groundwater-dependent mire areas, total groundwater influx to a peatland, or chemical composition of the water, peat hydraulic conductivity should also be considered, as it affects spatial GW-SW exchange patterns and groundwater flow paths.

- Peat geometry is less important when the total flux out of the system is of interest, e.g., the total amount of water discharging to a river or lake instead of the peatland. Groundwater exfiltration to peatlands is most pronounced: (1) when peat hydraulic 
conductivity is one order of magnitude lower than that of mineral soil, and (2) when peatland has low slope and the break in slope between hillslope and peatland is pronounced.

Model vertical discretization has little impact on model outputs when the mesh resolution is sufficiently high, but should be carefully chosen as coarser meshes, combined with discrete peat thickness representation, tend to misrepresent layers of variable thickness and could affect the magnitude of effective exchange flux.

Long-term groundwater drawdown in proximity of peatlands may not be clearly reflected in groundwater-fed peatland water levels, even if it significantly modifies the magnitude and spatial distribution of GW-SW interaction flux and, overall, the whole water balance of the peatland area. From a management viewpoint, this indicates that monitoring groundwater level alone is insufficient to verify the long-term influence of water abstraction on GW-SW interaction fluxes.

\section{Acknowledgments, and Data}

The first author was funded by the Aurora Doctoral Programme in Environment, Society and Technology in the North (Aurora-DP) of the University of Oulu and by personal grants received from the foundations: Maa- ja vesitekniikan tuki ry, Oulun läänin talousseuran maataloussäätiö, and Tauno Tönningin Säätiö. We would like to thank René Therrien and Aquanty Support Team for their assistance with the HydroGeoSphere software. The numerical data on which this study is based and model input files are available from Research data storage service IDA (ida.fairdata.fi) [will be uploaded when accepted for publication; for the review purpose please check a personal OneDrive folder: https://unioulumy.sharepoint.com/:f:/g/personal/ajaros_univ_yo_oulu_fi/EtJu0ry2ZtdIsweC3W-

\section{OheMBy9Ef4POWvM2SUkOFwqv1FA?e=cw70Ng ].}




\section{References}

Ala-aho, P., Rossi, P. M., Isokangas, E., \& Kløve, B. (2015). Fully integrated surfacesubsurface flow modelling of groundwater-lake interaction in an esker aquifer: Model verification with stable isotopes and airborne thermal imaging. Journal of Hydrology, 522, 391-406. https://doi.org/10.1016/j.jhydrol.2014.12.054

Ala-aho, P., Soulsby, C., Wang, H., \& Tetzlaff, D. (2017). Integrated surface-subsurface model to investigate the role of groundwater in headwater catchment runoff generation: A minimalist approach to parameterisation. Journal of Hydrology, 547, 664-677. https://doi.org/10.1016/j.jhydrol.2017.02.023

Aldous, A. R., \& Bach, L. B. (2014). Hydro-ecology of groundwater-dependent ecosystems: applying basic science to groundwater management. Hydrological Sciences Journal, 59(3-4), 530-544. https://doi.org/10.1080/02626667.2014.889296

Anderson, M. P., Woessner, W. W., \& Hunt, R. J. (2015). Chapter 4 - Model Dimensionality and Setting Boundaries. In M. P. Anderson, W. W. Woessner, \& R. J. Hunt (Eds.), Applied Groundwater Modeling (Second Edition) (Second Edi, pp. 117-180). San Diego: Academic Press. https://doi.org/https://doi.org/10.1016/B978-0-08-091638-5.00004-3

Aquanty. (2015). HydroGeoSphere User Manual. Release 1. Waterloo, Ontario, Canada: Aquanty Inc.

Baird, A.J., Eades, P.A. and Surridge, B.W.J. (2008), The hydraulic structure of a raised bog and its implications for ecohydrological modelling of bog development. Ecohydrology, 1: 289-298. doi:10.1002/eco.33

Barthel, R. (2014). HESS Opinions \&amp;quot;Integration of groundwater and surface water research: an interdisciplinary problem?\&amp;quot; Hydrology and Earth System Sciences, 18(7), 2615-2628. https://doi.org/10.5194/hess-18-2615-2014

Barthel, Roland, \& Banzhaf, S. (2016). Groundwater and Surface Water Interaction at the Regional-scale - A Review with Focus on Regional Integrated Models. Water Resources Management, 30(1), 1-32. https://doi.org/10.1007/s11269-015-1163-z

Bechtold, M., Schlaffer, S., Tiemeyer, B., \& De Lannoy, G. (2018). Inferring Water Table Depth Dynamics from ENVISAT-ASAR C-Band Backscatter over a Range of Peatlands from Deeply-Drained to Natural Conditions. Remote Sensing, 10(4), 536. https://doi.org/10.3390/rs10040536

Beckwith, C.W., Baird, A.J. and Heathwaite, A.L. (2003), Anisotropy and depth-related heterogeneity of hydraulic conductivity in a bog peat. I: laboratory measurements. Hydrological Processes, 17: 89-101. doi:10.1002/hyp.1116

Blessent, D., Barco, J., Temgoua, A. G. T., \& Echeverrri-Ramirez, O. (2017). Coupled surface and subsurface flow modeling of natural hillslopes in the Aburrá Valley (Medellín, Colombia). Hydrogeology Journal, 25(2), 331-345. https://doi.org/10.1007/s10040-016$1482-\mathrm{z}$

Briggs, M. A., Hare, D. K., Boutt, D. F., Davenport, G., \& Lane, J. W. (2016). Thermal infrared video details multiscale groundwater discharge to surface water through macropores and peat pipes. Hydrological Processes, 30(14), 2510-2511. https://doi.org/10.1002/hyp.10722

Brunner, P., \& Simmons, C. T. (2012). HydroGeoSphere: A Fully Integrated, Physically Based Hydrological Model. Groundwater, 50(2), 170-176. https://doi.org/10.1111/j.1745- 
6584.2011.00882.x

Carrera-Hernández, J. J., Smerdon, B. D., \& Mendoza, C. A. (2012). Estimating groundwater recharge through unsaturated flow modelling: Sensitivity to boundary conditions and vertical discretization. Journal of Hydrology, 452-453, 90-101. https://doi.org/10.1016/j.jhydrol.2012.05.039

Chow, R., Wu, H., Bennett, J., Dugge, J., Wöhling, T., \& Nowak, W. (2018). Sensitivity of simulated hyporheic exchange to river bathymetry: The Steinlach River Test Site. Groundwater, (0). https://doi.org/10.1111/gwat.12816

Downer, C. W., \& Ogden, F. L. (2004). Appropriate vertical discretization of Richards' equation for two-dimensional watershed-scale modelling. Hydrological Processes, 18(1), 1-22. https://doi.org/10.1002/hyp.1306

Drexler, J. Z., Bedford, B. L., Scognamiglio, R., \& Siegel, D. I. (1999). Fine-scale characteristics of groundwater flow in a peatland. Hydrological Processes, 13(9), 13411359. https://doi.org/10.1002/(SICI)1099-1085(19990630)13:9<1341::AIDHYP810>3.0.CO;2-5

Dureijka, S. (2013). A modeling approach to evaluate groundwater-surface water exchange in a Canadian wetland using a physically based model. University of Bayreuth.

Ebel, B. A., Mirus, B. B., Heppner, C. S., VanderKwaak, J. E., \& Loague, K. (2009). Firstorder exchange coefficient coupling for simulating surface water-groundwater interactions: Parameter sensitivity and consistency with a physics-based approach. Hydrological Processes, 23(13), 1949-1959. https://doi.org/10.1002/hyp.7279

Eskelinen, R., Ala-aho, P., Rossi, P. M., \& Kløve, B. (2015). A GIS-based method for predicting groundwater discharge areas in esker aquifers in the Boreal region. Environmental Earth Sciences, 74(5), 4109-4118. https://doi.org/10.1007/s12665-0154491-7

Farthing, M. W., \& Ogden, F. L. (2017). Numerical Solution of Richards' Equation: A Review of Advances and Challenges. Soil Science Society of America Journal, 81(6), 1257-1269. https://doi.org/10.2136/sssaj2017.02.0058

Fetter, C. W. (2014). Applied Hydrogeology (Fourth Edi). Harlow, UK: Pearson Education Limited.

Fraser, C. J. D., Roulet, N. T., \& Lafleur, M. (2001). Groundwater flow patterns in a large peatland. Journal of Hydrology, 246(1-4), 142-154. https://doi.org/10.1016/S00221694(01)00362-6

Frei, S., \& Fleckenstein, J. H. (2014). Representing effects of micro-topography on runoff generation and sub-surface flow patterns by using superficial rill/depression storage height variations. Environmental Modelling \& Software, 52, 5-18. https://doi.org/10.1016/j.envsoft.2013.10.007

Frei, S., Lischeid, G., \& Fleckenstein, J. H. (2010). Effects of micro-topography on surfacesubsurface exchange and runoff generation in a virtual riparian wetland - A modeling study. Advances in Water Resources, 33(11), 1388-1401. https://doi.org/10.1016/j.advwatres.2010.07.006

Frei, S., Knorr, K. H., Peiffer, S., \& Fleckenstein, J. H. (2012). Surface micro-topography causes hot spots of biogeochemical activity in wetland systems: A virtual modeling experiment. Journal of Geophysical Research: Biogeosciences, 117(G4), G00N12. 
https://doi.org/10.1029/2012JG002012

Glaser, B., Klaus, J., Frei, S., Frentress, J., Pfister, L., \& Hopp, L. (2016). On the value of surface saturated area dynamics mapped with thermal infrared imagery for modeling the hillslope-riparian-stream continuum. Water Resources Research, 52(10), 8317-8342. https://doi.org/10.1002/2015WR018414

Gleeson, T., \& Manning, A. H. (2008). Regional groundwater flow in mountainous terrain: Three-dimensional simulations of topographic and hydrogeologic controls. Water Resources Research, 44(10), W10403. https://doi.org/10.1029/2008WR006848

Gorham, E. (1991). Northern Peatlands : Role in the Carbon Cycle and Probable Responses to Climatic Warming. Ecological Applications, 1(2), 182-195. https://doi.org/10.2307/1941811

Haahti, K., Marttila, H., Warsta, L., Kokkonen, T., Finér, L., \& Koivusalo, H. (2016). Modeling sediment transport after ditch network maintenance of a forested peatland. Water Resources Research, 52(11), 9001-9019. https://doi.org/10.1002/2016WR019442

Haahti, Kersti, Warsta, L., Kokkonen, T., Younis, B. A., \& Koivusalo, H. (2016). Distributed hydrological modeling with channel network flow of a forestry drained peatland site. Water Resources Research, 52(1), 246-263. https://doi.org/10.1002/2015WR018038

Haahti, Kersti, Nieminen, M., Finér, L., Marttila, H., Kokkonen, T., Leinonen, A., \& Koivusalo, H. (2018). Model-based evaluation of sediment control in a drained peatland forest after ditch network maintenance. Canadian Journal of Forest Research, 48(2), 130 140. https://doi.org/10.1139/cjfr-2017-0269

Hare, D. K., Briggs, M. A., Rosenberry, D. O., Boutt, D. F., \& Lane, J. W. (2015). A comparison of thermal infrared to fiber-optic distributed temperature sensing for evaluation of groundwater discharge to surface water. Journal of Hydrology, 530, 153166. https://doi.org/10.1016/j.jhydrol.2015.09.059

Hare, D. K., Boutt, D. F., Clement, W. P., Hatch, C. E., Davenport, G., \& Hackman, A. (2017). Hydrogeological controls on spatial patterns of groundwater discharge in peatlands. Hydrology and Earth System Sciences, 21(12), 6031-6048. https://doi.org/10.5194/hess21-6031-2017

Holden, J., \& Burt, T. P. (2002). Piping and pipeflow in a deep peat catchment. Catena, 48(3), 163-199. https://doi.org/10.1016/S0341-8162(01)00189-8

Holden, J., \& Burt, T. P. (2003). Hydraulic conductivity in upland blanket peat: Measurement and variability. Hydrological Processes, 17(6), 1227-1237. https://doi.org/10.1002/hyp.1182

Hwang, H.-T., Park, Y.-J., Sudicky, E. A., Berg, S. J., McLaughlin, R., \& Jones, J. P. (2018). Understanding the water balance paradox in the Athabasca River Basin, Canada. Hydrological Processes, 32(6), 729-746. https://doi.org/10.1002/hyp.11449

Isokangas, E., Rossi, P. M., Ronkanen, A.-K., Marttila, H., Rozanski, K., \& Kløve, B. (2017). Quantifying spatial groundwater dependence in peatlands through a distributed isotope mass balance approach. Water Resources Research, 53(3), 2524-2541. https://doi.org/10.1002/2016WR019661

Jaros, A. (2015). Integrated groundwater-surface water model to manage springs, streams, lakes and fens: conditions in Kälväsvaara case, Finland (Master's thesis, Faculty of Technology, Environmental Engineering). University of Oulu, Finland. 
Jaros, A., Rossi, P. M., Ronkanen, A.-K., \& Kløve, B. (2019). Parameterisation of an integrated groundwater-surface water model for hydrological analysis of boreal aapa mire wetlands. Journal of Hydrology, 575, 175-191. https://doi.org/10.1016/j.jhydrol.2019.04.094

Johansen, O. M., Pedersen, M. L., \& Jensen, J. B. (2011). Effect of groundwater abstraction on fen ecosystems. Journal of Hydrology, 402(3-4), 357-366. https://doi.org/10.1016/j.jhydrol.2011.03.031

Jones, J. P., Sudicky, E. A., \& McLaren, R. G. (2008). Application of a fully-integrated surfacesubsurface flow model at the watershed-scale: A case study. Water Resources Research, 44(3). https://doi.org/10.1029/2006WR005603

Koch, J. C., Toohey, R. C., \& Reeves, D. M. (2017). Tracer-based evidence of heterogeneity in subsurface flow and storage within a boreal hillslope. Hydrological Processes, 31(13), 2453-2463. https://doi.org/10.1002/hyp.11205

Kolditz, O., Bauer, S., Bilke, L., Böttcher, N., Delfs, J. O., Fischer, T., et al. (2012). OpenGeoSys: an open-source initiative for numerical simulation of thermo-hydromechanical/chemical (THM/C) processes in porous media. Environmental Earth Sciences, 67(2), 589-599. https://doi.org/10.1007/s12665-012-1546-X

Kollet, S., Sulis, M., Maxwell, R. M., Paniconi, C., Putti, M., Bertoldi, G., et al. (2017). The integrated hydrologic model intercomparison project, IH-MIP2: A second set of benchmark results to diagnose integrated hydrology and feedbacks. Water Resources Research, 53(1), 867-890. https://doi.org/10.1002/2016WR019191

Kollet, S. J., \& Maxwell, R. M. (2006). Integrated surface-groundwater flow modeling: A freesurface overland flow boundary condition in a parallel groundwater flow model. Advances in Water Resources, 29(7), 945-958. https://doi.org/10.1016/j.advwatres.2005.08.006

Lewis, C., Albertson, J., Xu, X. and Kiely, G. (2012), Spatial variability of hydraulic conductivity and bulk density along a blanket peatland hillslope. Hydrological Processes, 26: 1527-1537. doi:10.1002/hyp.8252

Letniowski, F. W., \& Forsyth, P. A. (1991). A control volume finite element method for threedimensional NAPL groundwater contamination. International Journal for Numerical Methods in Fluids, 13(8), 955-970. https://doi.org/10.1002/fld.1650130803

Levy, Z. F., Siegel, D. I., Dasgupta, S. S., Glaser, P. H., \& Welker, J. M. (2014). Stable isotopes of water show deep seasonal recharge in northern bogs and fens. Hydrological Processes, 28(18), 4938-4952. https://doi.org/10.1002/hyp.9983

Levy, Z. F., Siegel, D. I., Glaser, P. H., Samson, S. D., \& Dasgupta, S. S. (2016). Peat porewaters have contrasting geochemical fingerprints for groundwater recharge and discharge due to matrix diffusion in a large, northern bog-fen complex. Journal of Hydrology, 541, 941-951. https://doi.org/10.1016/j.jhydrol.2016.08.001

Liggett, J. E., Werner, A. D., \& Simmons, C. T. (2012). Influence of the first-order exchange coefficient on simulation of coupled surface-subsurface flow. Journal of Hydrology, 414415, 503-515. https://doi.org/10.1016/j.jhydrol.2011.11.028

Lin, X., Green, S., Tfaily, M. M., Prakash, O., Konstantinidis, K. T., Corbett, J. E., et al. (2012). Microbial Community Structure and Activity Linked to Contrasting Biogeochemical Gradients in Bog and Fen Environments of the Glacial Lake Agassiz Peatland. Applied and Environmental Microbiology, 78(19), 7023-7031. https://doi.org/10.1128/AEM.01750-12 
Liu, G., Schwartz, F. W., Wright, C. K., \& McIntyre, N. E. (2016). Characterizing the climatedriven collapses and expansions of wetland habitats with a fully integrated surfacesubsurface hydrologic model. Wetlands, 36(2), 287-297. https://doi.org/10.1007/s13157016-0817-9

Lowry, C. S., Fratta, D., \& Anderson, M. P. (2009). Ground penetrating radar and spring formation in a groundwater dominated peat wetland. Journal of Hydrology, 373(1-2), 6879. https://doi.org/10.1016/j.jhydrol.2009.04.023

Maxwell, R. M., Putti, M., Meyerhoff, S., Delfs, J.-O., Ferguson, I. M., Ivanov, V., et al. (2014). Surface-subsurface model intercomparison: A first set of benchmark results to diagnose integrated hydrology and feedbacks. Water Resources Research, 50(2), 15311549. https://doi.org/10.1002/2013WR013725

McLachlan, P. J., Chambers, J. E., Uhlemann, S. S., \& Binley, A. (2017). Geophysical characterisation of the groundwater-surface water interface. Advances in Water Resources, 109, 302-319. https://doi.org/10.1016/j.advwatres.2017.09.016

Menberu, M. W., Tahvanainen, T., Marttila, H., Irannezhad, M., Ronkanen, A.-K., Penttinen, J., \& Kløve, B. (2016). Water-table-dependent hydrological changes following peatland forestry drainage and restoration: Analysis of restoration success. Water Resources Research, 52(5), 3742-3760. https://doi.org/10.1002/2015WR018578

Mitchell, C. P. J., \& Branfireun, B. A. (2005). Hydrogeomorphic controls on reductionoxidation conditions across boreal upland-peatland interfaces. Ecosystems, 8(7), 731-747. https://doi.org/10.1007/s10021-005-1792-9

Nadeau, S., Rosa, E., Cloutier, V., Daigneault, R.-A., \& Veillette, J. (2015). A GIS-based approach for supporting groundwater protection in eskers: Application to sand and gravel extraction activities in Abitibi-Témiscamingue, Quebec, Canada. Journal of Hydrology: Regional Studies, 4, 535-549. https://doi.org/10.1016/j.ejrh.2015.05.015

National Land Survey of Finland. (2014). Elevation model data (grid size: 10m x 10m). [Map Raster].

Négrel, P., Millot, R., Brenot, A., \& Bertin, C. (2010). Lithium isotopes as tracers of groundwater circulation in a peat land. Chemical Geology, 276(1-2), 119-127. https://doi.org/10.1016/j.chemgeo.2010.06.008

Okkonen, J., \& Kløve, B. (2011). A sequential modelling approach to assess groundwatersurface water resources in a snow dominated region of Finland. Journal of Hydrology, 411(1-2), 91-107. https://doi.org/10.1016/j.jhydrol.2011.09.038

Päivänen, J. (1973). Hydraulic conductivity and water retention in peat soils. Acta Forestalia Fennica 129. Helsinki, Finland: Suomen Metsätieteellinen Seura.

Partington, D., Brunner, P., Frei, S., Simmons, C. T., Werner, A. D., Therrien, R., et al. (2013). Interpreting streamflow generation mechanisms from integrated surface-subsurface flow models of a riparian wetland and catchment. Water Resources Research, 49(9), 55015519. https://doi.org/10.1002/wrcr.20405

Post, V. E. A., \& von Asmuth, J. R. (2013). Review: Hydraulic head measurements-new technologies, classic pitfalls. Hydrogeology Journal, 21(4), 737-750. https://doi.org/10.1007/s10040-013-0969-0

Quillet, A., Larocque, M., Pellerin, S., Cloutier, V., Ferlatte, M., Paniconi, C., \& Bourgault, M.-A. (2017). The role of hydrogeological setting in two Canadian peatlands investigated 
through 2D steady-state groundwater flow modelling. Hydrological Sciences Journal, 62(15), 2541-2557. https://doi.org/10.1080/02626667.2017.1391387

Rau, G. C., Post, V. E. A., Shanafield, M. A., Krekeler, T., Banks, E. W., \& Blum, P. (2019). Error in hydraulic head and gradient time-series measurements: a quantitative appraisal. Hydrology and Earth System Sciences Discussions, (April), 1-41. https://doi.org/10.5194/hess-2019-182

Refsgaard, J. C. (1997). Parameterisation, calibration and validation of distributed hydrological models. Journal of Hydrology, 198(1-4), 69-97. https://doi.org/10.1016/S00221694(96)03329-X

Richards, L. A. (1931). Capillary conduction of liquids throuhg porous mediums. Journal of Applied Physics, 1(5), 318-333. https://doi.org/10.1063/1.1745010

Rosa, E. and Larocque, M. (2008), Investigating peat hydrological properties using field and laboratory methods: application to the Lanoraie peatland complex (southern Quebec, Canada). Hydrological Processes, 22: 1866-1875. doi:10.1002/hyp.6771

Rossi, P. M., Ala-aho, P., Ronkanen, A.-K., \& Kløve, B. (2012). Groundwater-surface water interaction between an esker aquifer and a drained fen. Journal of Hydrology, 432-433, 52-60. https://doi.org/10.1016/j.jhydrol.2012.02.026

Schilling, O. S., Cook, P. G., \& Brunner, P. (2019). Beyond Classical Observations in Hydrogeology: The Advantages of Including Exchange Flux, Temperature, Tracer Concentration, Residence Time, and Soil Moisture Observations in Groundwater Model Calibration. Reviews of Geophysics, 57(1), 146-182. https://doi.org/10.1029/2018RG000619

Sciuto, G., \& Diekkrüger, B. (2010). Influence of Soil Heterogeneity and Spatial Discretization on Catchment Water Balance Modeling. Vadose Zone Journal, 9(4), 955-969. https://doi.org/10.2136/vzj2009.0166

Smerdon, B. D., Mendoza, C. A., \& Devito, K. J. (2007). Simulations of fully coupled lakegroundwater exchange in a subhumid climate with an integrated hydrologic model. Water Resources Research, 43(1), W01416. https://doi.org/10.1029/2006WR005137

Tahvanainen, T. (2011). Abrupt ombrotrophication of a boreal aapa mire triggered by hydrological disturbance in the catchment. Journal of Ecology, 99. https://doi.org/10.1111/j.1365-2745.2010.01778.x

Thompson, C., Mendoza, C. A., Devito, K. J., \& Petrone, R. M. (2015). Climatic controls on groundwater-surface water interactions within the Boreal Plains of Alberta: Field observations and numerical simulations. Journal of Hydrology, 527, 734-746. https://doi.org/10.1016/j.jhydrol.2015.05.027

Thompson, C., Mendoza, C. A., \& Devito, K. J. (2017). Potential influence of climate change on ecosystems within the Boreal Plains of Alberta. Hydrological Processes, 31(11), 21102124. https://doi.org/10.1002/hyp.11183

Thompson, L. R., Sanders, J. G., McDonald, D., Amir, A., Ladau, J., Locey, K. J., et al. (2017). A communal catalogue reveals Earth's multiscale microbial diversity. Nature, 551, 457463. https://doi.org/10.1038/nature24621

Tóth, J. (1963). A theoretical analysis of groundwater flow in small drainage basins. Journal of Geophysical Research, 68(16), 4795-4812. https://doi.org/10.1029/JZ068i016p04795

Turunen, J., Tomppo, E., Tolonen, K., \& Reinikainen, A. (2002). Estimating carbon 
accumulation rates of undrained mires in Finland-application to boreal and subarctic regions. The Holocene, 12(1), 69-80. https://doi.org/10.1191/0959683602hl522rp

Vogel, H.-J., \& Ippisch, O. (2008). Estimation of a Critical Spatial Discretization Limit for Solving Richards' Equation at Large Scales. Vadose Zone Journal, 7, 112-114. https://doi.org/10.2136/vzj2006.0182

Waddington, J. M., \& Roulet, N. T. (1997). Groundwater flow and dissolved carbon movement in a boreal peatland. Journal of Hydrology, 191(1-4), 122-138. https://doi.org/10.1016/S0022-1694(96)03075-2

Wildemeersch, S., Goderniaux, P., Orban, P., Brouyère, S., \& Dassargues, A. (2014). Assessing the effects of spatial discretization on large-scale flow model performance and prediction uncertainty. Journal of Hydrology, 510, 10-25. https://doi.org/10.1016/j.jhydrol.2013.12.020

Winter, T. C., Harvey, J. W., Franke, O. L., \& Alley, W. M. (1998). Ground water and surface water: A single resource (U.S. Geological Survey Circular 79). Denver, Colorado, USA: US Geological Survey.
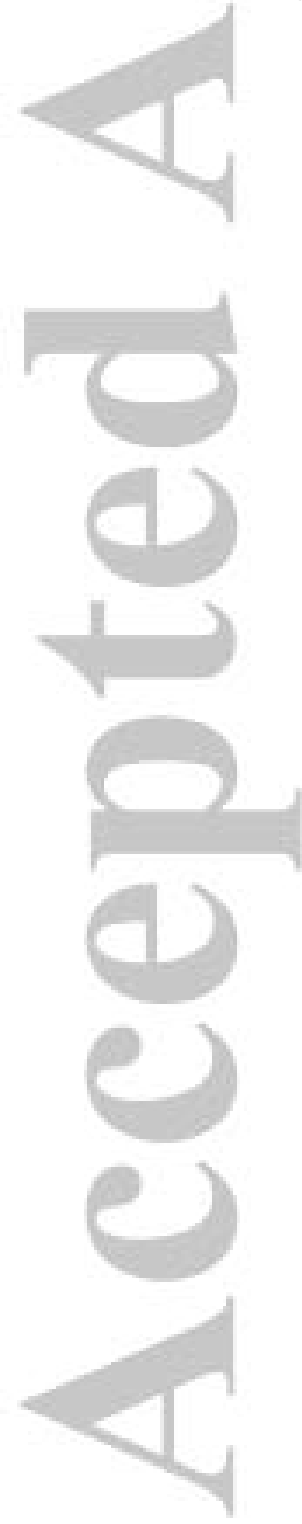
a)

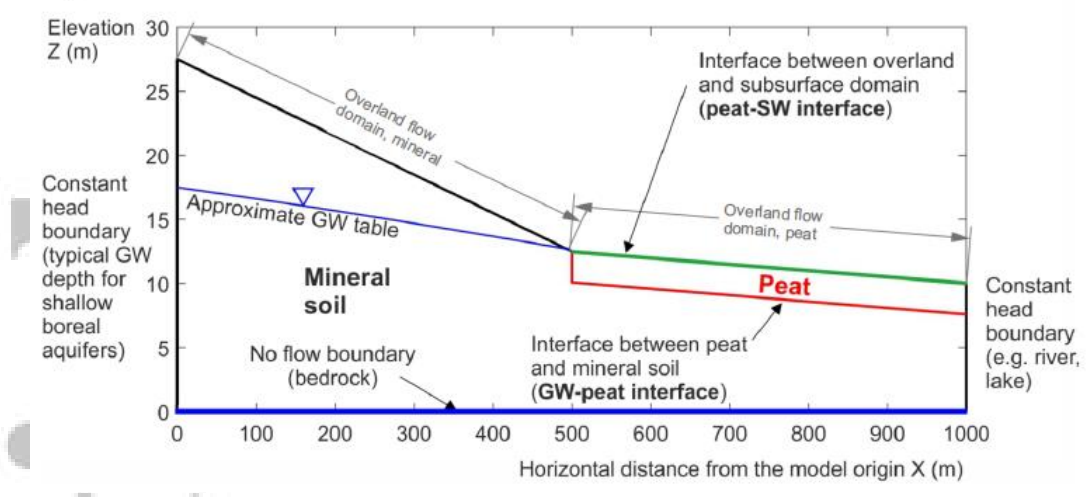

b)
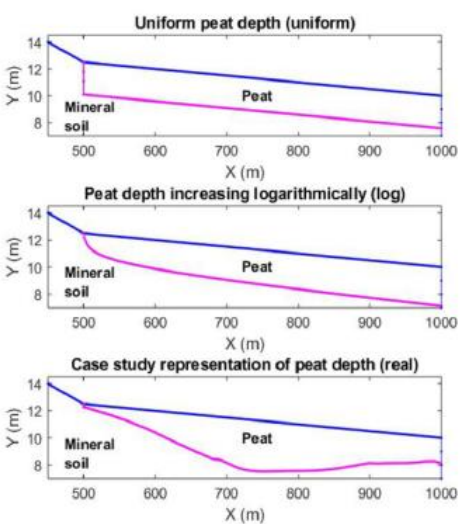

Figure 1. (a) Two-dimensional model domain and conceptualization of GW-SW interfaces in peatlands. 'Overland mineral' and 'overland peat' indicate surface flow zones for forest and peat, respectively. (b) Peat geometry in three types of conceptual models considered in this study. 
a)

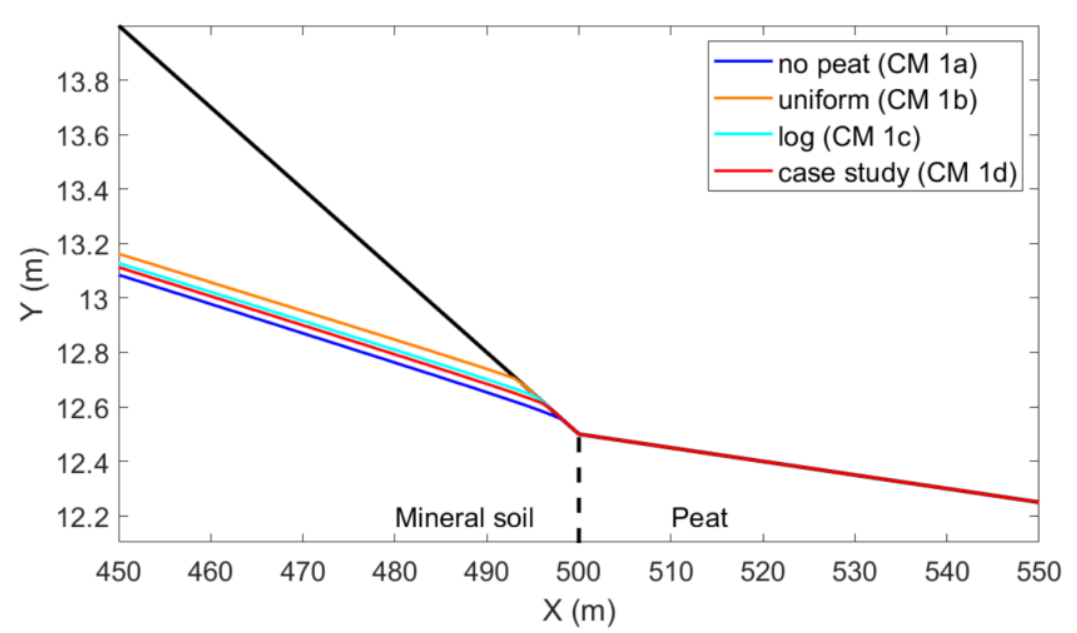

b)

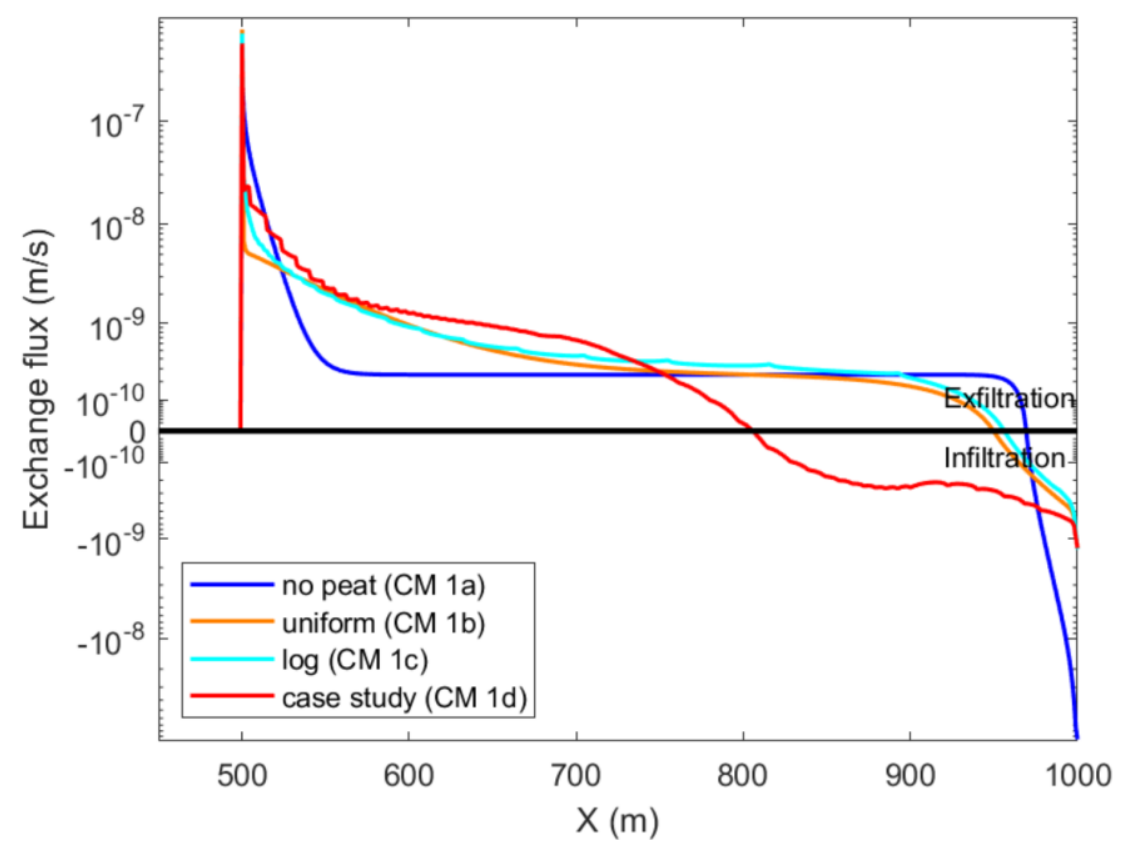

Figure 2. (a) Detailed diagram of groundwater elevation at the interface of mineral soil and peatland in different peat soil geometry conceptual models (CM). (b) Exchange flux for peat soil layer geometry conceptual models (CMs 1a-d). Positive groundwater-surface water (GW-SW) exchange flux values indicate locations of groundwater discharge to overland zone, negative values indicate areas where water infiltrates to the subsurface. The diagram shows averaged nodal exchange fluxes (total nodal fluxes divided by an influence area of the node), plotted for visualization purposes as a continuous dataset. 
- a)

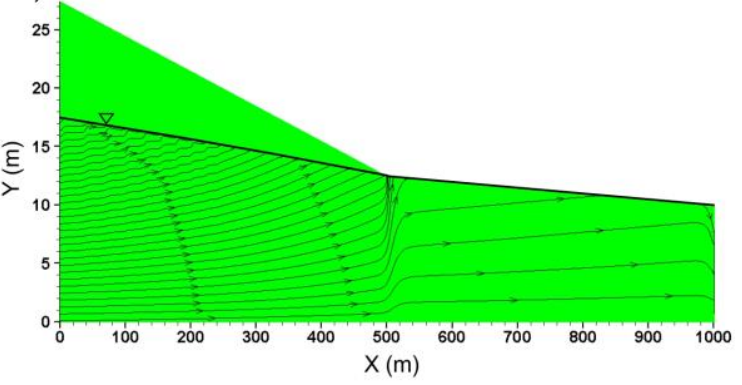

c)

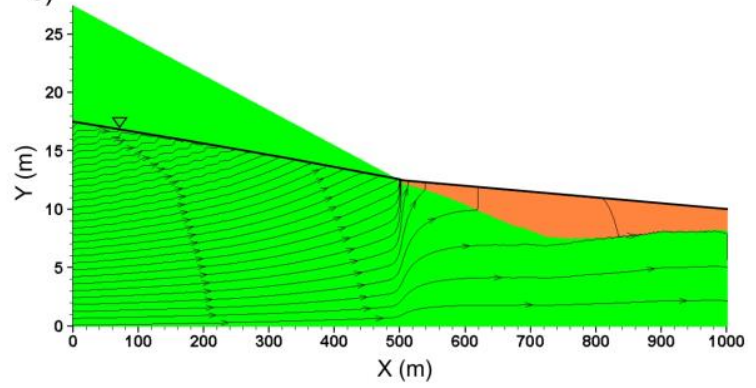

b)

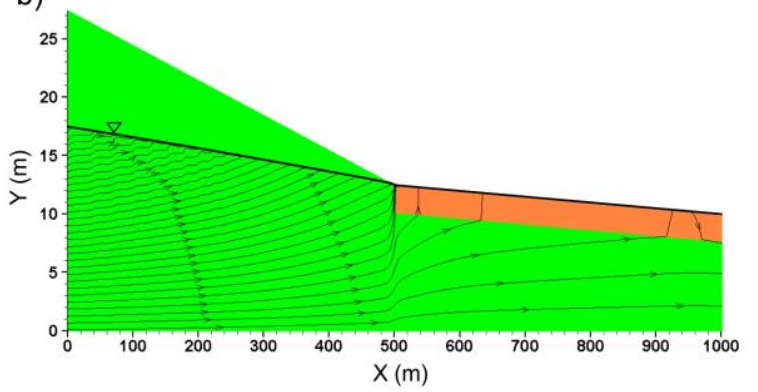

d)

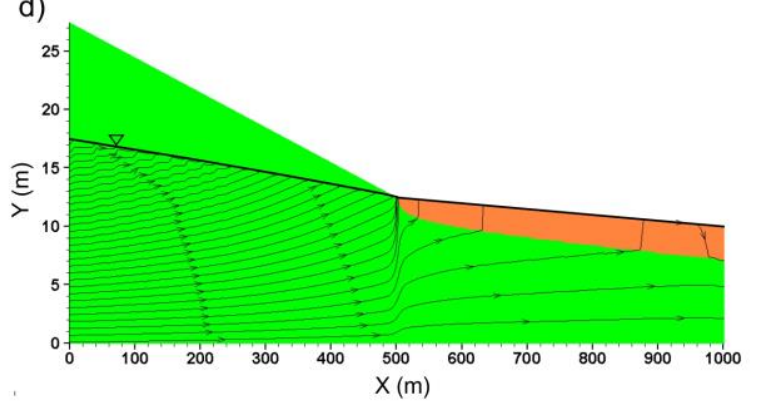

Figure 3. Stream traces in the peat soil geometry conceptual models (CM) for (a) no peat (CM 1a), (b) uniform peat (CM 1b), (c) logarithmically changing peat (CM 1c), and (d) case study (CM 1d). Stream traces were generated using Tecplot 360 EX 2015 Release 2. 


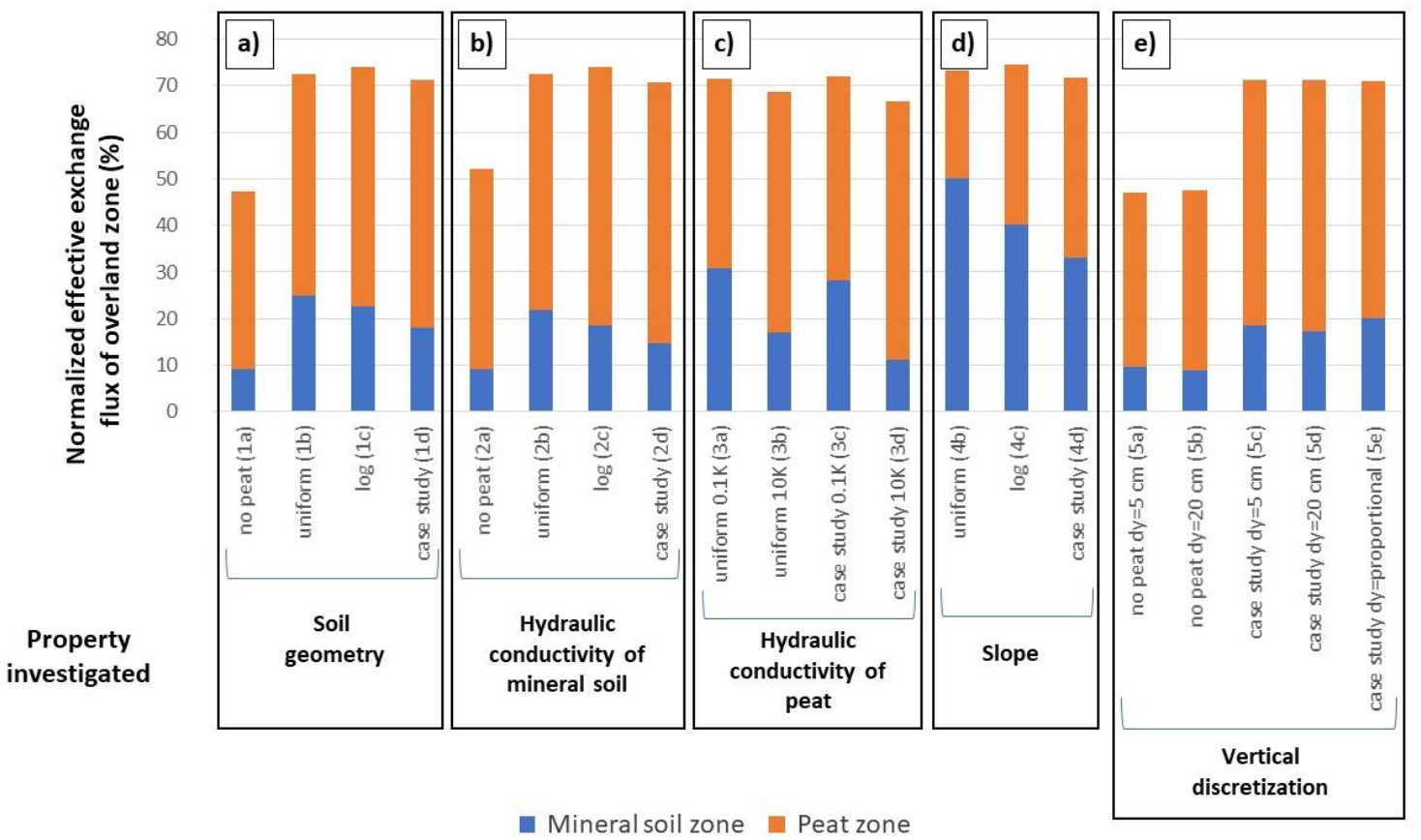

Figure 4. Normalized effective exchange flux of overland zone in (a-e) different conceptual models (CMs 1-5). Flux is represented as a percentage of the total groundwater inflow through the steady head boundary condition at the left edge of the system. The amount of water flowing through the left boundary condition differed for differing mineral soil hydraulic conductivity and slope cases. 


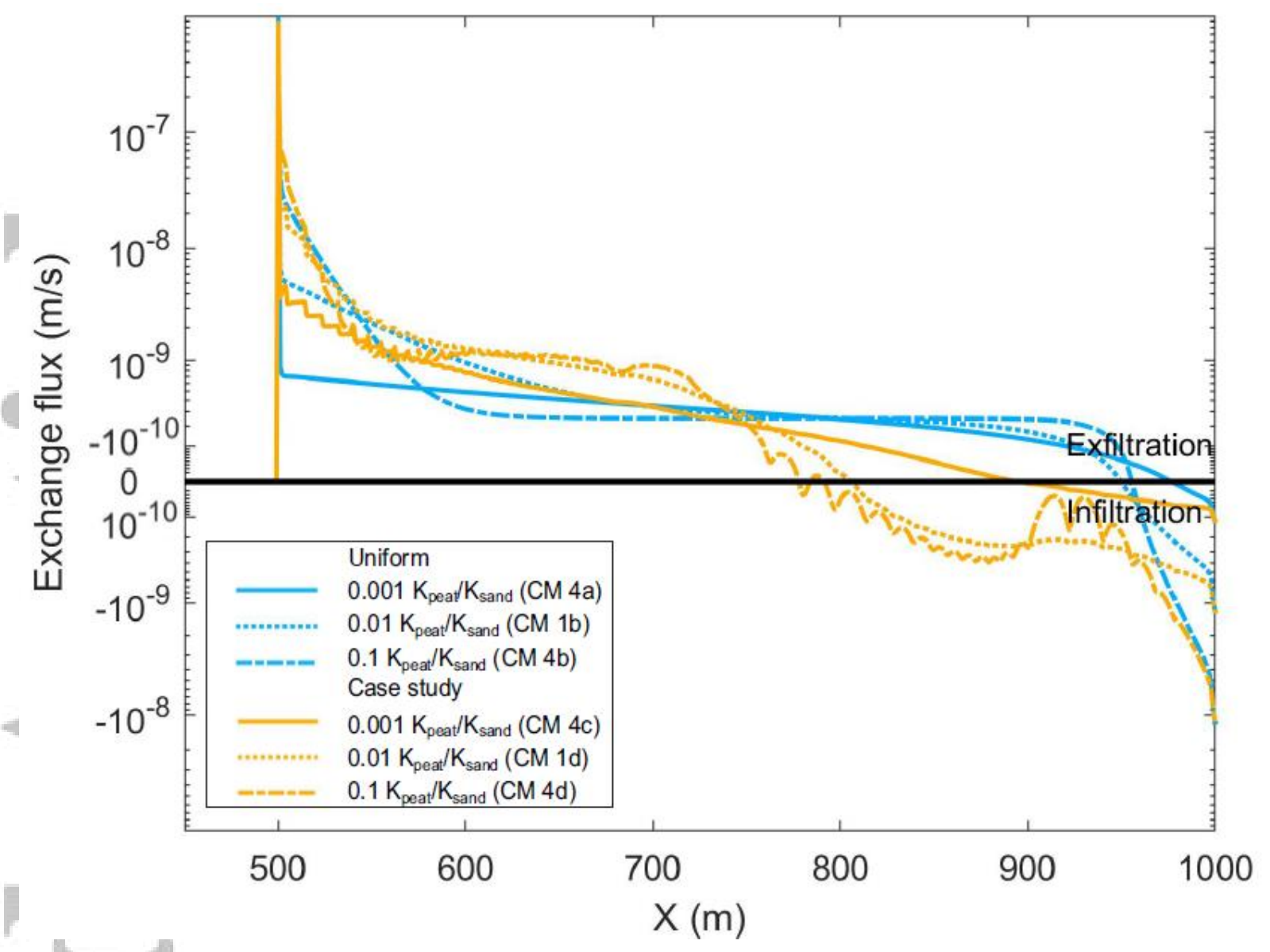

Figure 5. Exchange fluxes for conceptual models (CMs) $4 a-d$ varying the $K_{\text {peat }} / K_{\text {sand }}$ ratio by differing peat hydraulic conductivity. Plotted with reference to the uniform peat (CM $1 b)$ and case study peat soil layer (CM 1d) geometry representations. Positive groundwater-surface water (GW-SW) exchange flux values indicate locations of groundwater discharge to overland zone, negative values indicate areas where water infiltrates to the subsurface. The diagram shows averaged nodal exchange fluxes (total nodal fluxes divided by an influence area of the node), plotted for visualization purposes as a continuous dataset. 
a)
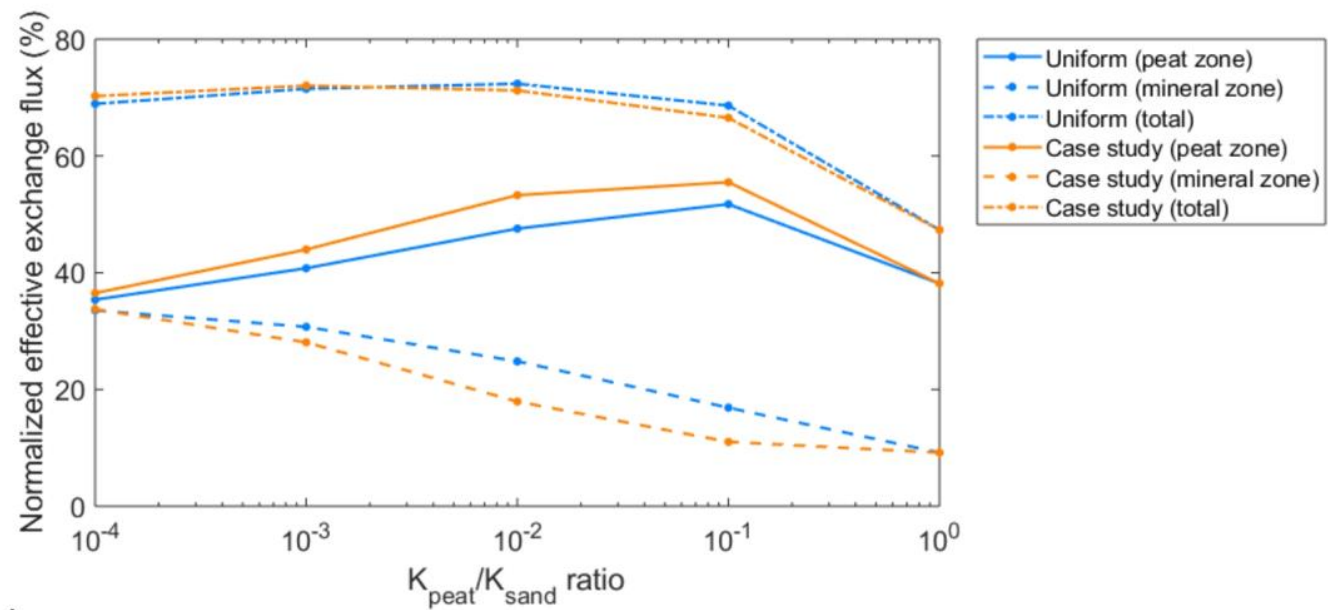

b)
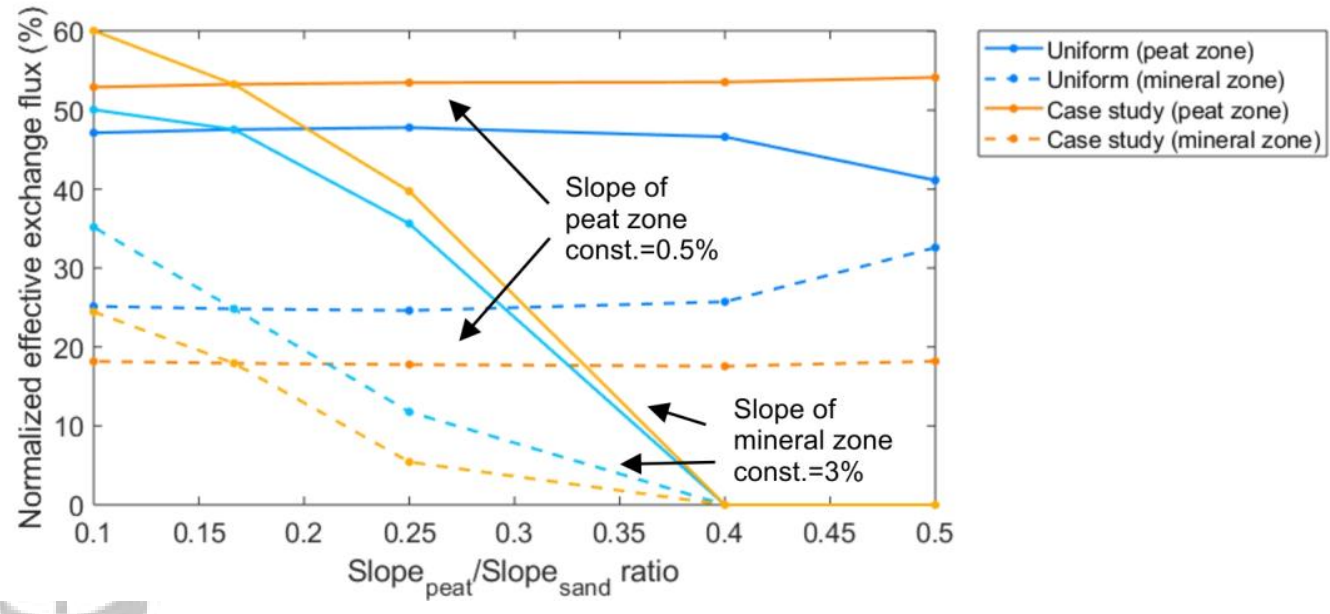

Figure 6. (a) Normalized effective exchange fluxes for various peat soil geometries and hydraulic conductivity $K_{\text {peat }} / K_{\text {sand }}$ ratios, in which $K_{\text {peat }}$ varies between $1.0 \mathrm{E}-9$ and $1 . \mathrm{E}-5 \mathrm{~m} / \mathrm{s}$.

(b) Normalized effective exchange flux of overland zone for various peat soil layer geometries and slope ratios, in which i) slope of mineral slope varies between $0.75 \%$ and 5 and slope of peat zone is kept constant and ii) slope of peat zone varies between 0.3 and $2 \%$ and slope of mineral zone is kept constant. 


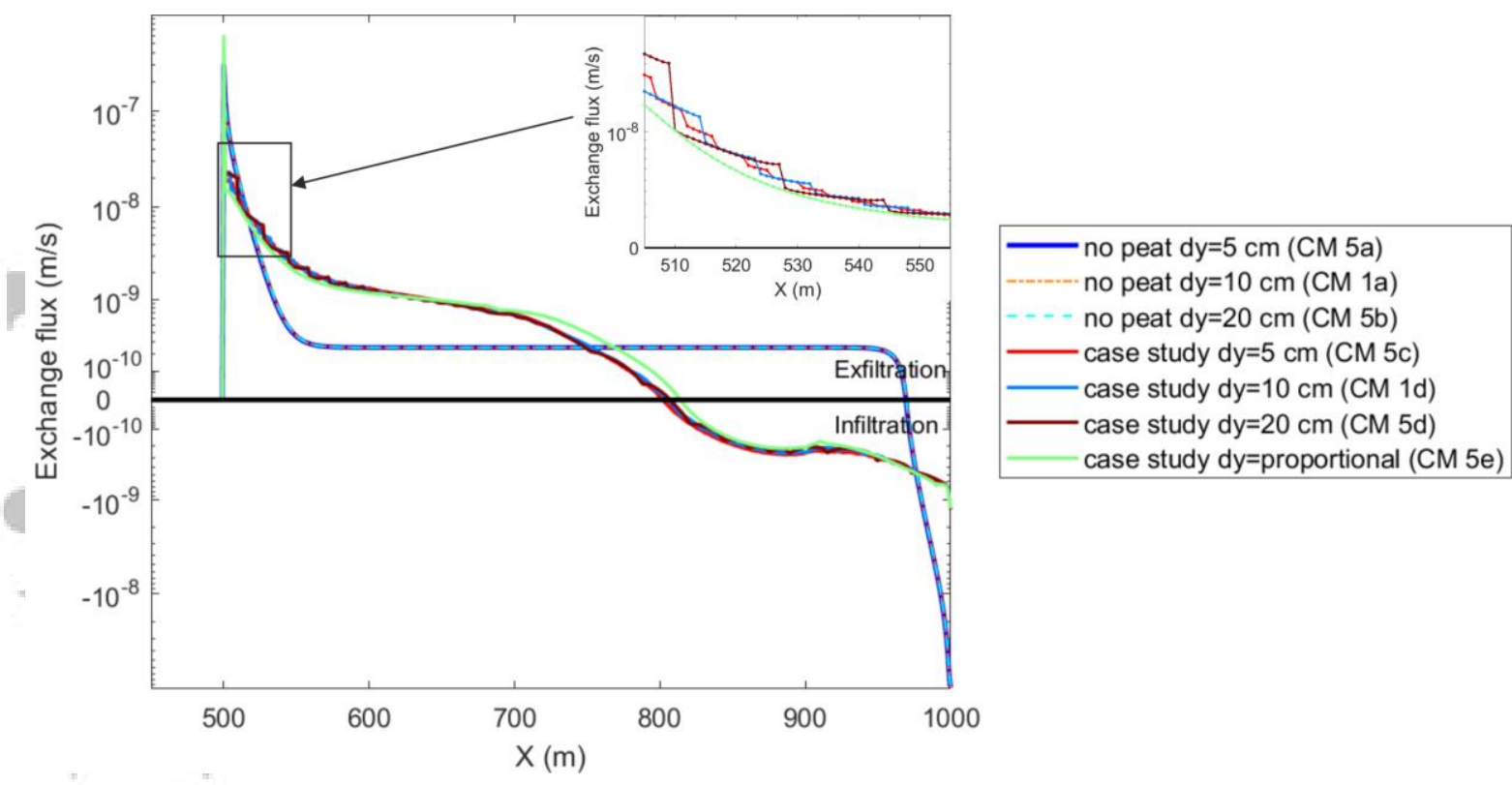

Figure 7. Exchange fluxes for conceptual models (CMs) 5a-d differing in terms of vertical discretization (dy) plotted with reference to no peat $\mathrm{CM} 1 \mathrm{a}$ (no peat $\mathrm{dy}=10 \mathrm{~cm}$ ) and case study peat soil layer geometry representation CM $1 \mathrm{~d}$ (case study $\mathrm{dy}=10 \mathrm{~cm}$ ); all other settings in the models were the same as in the reference model. Positive groundwater-surface water (GW-

SW) exchange flux values indicate locations of groundwater discharge to overland zone, negative values indicate areas where water infiltrates to the subsurface. The diagram shows averaged nodal exchange fluxes (total nodal fluxes divided by an influence area of the node), plotted for visualization purposes as a continuous dataset. 

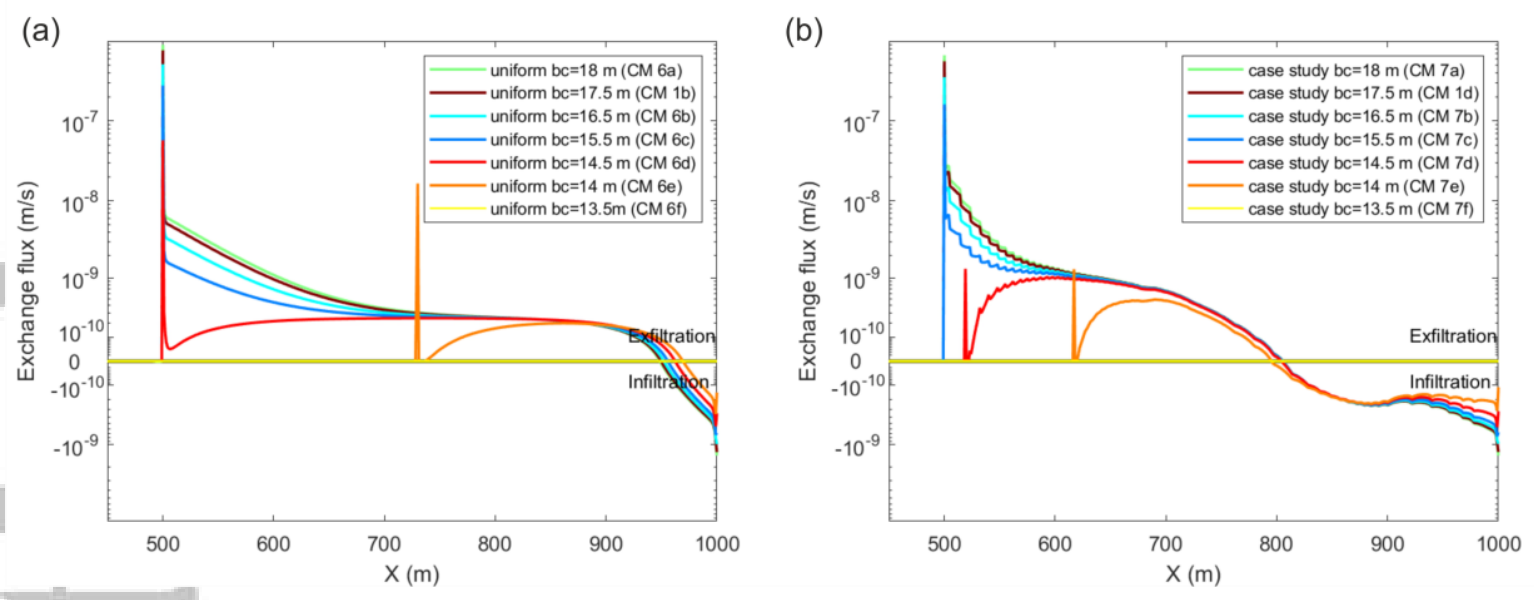

Figure 8. Exchange flux in the wetland area (x-axis 500-1000 m) for changing boundary conditions representing long-term pumping $(b c=13.5-16.5 \mathrm{~m})$ and wet conditions $(18 \mathrm{~m})$ in comparison with the reference model $(b c=17.5 \mathrm{~m})$ for $(a)$ the uniform and $(b)$ the case study peat soil layer geometry representations. Positive groundwater-surface water (GW-SW) exchange flux values indicate locations of groundwater discharge to overland zone, negative values indicate areas where water infiltrates to the subsurface. The diagrams show averaged nodal exchange fluxes (total nodal fluxes divided by an influence area of the node), plotted

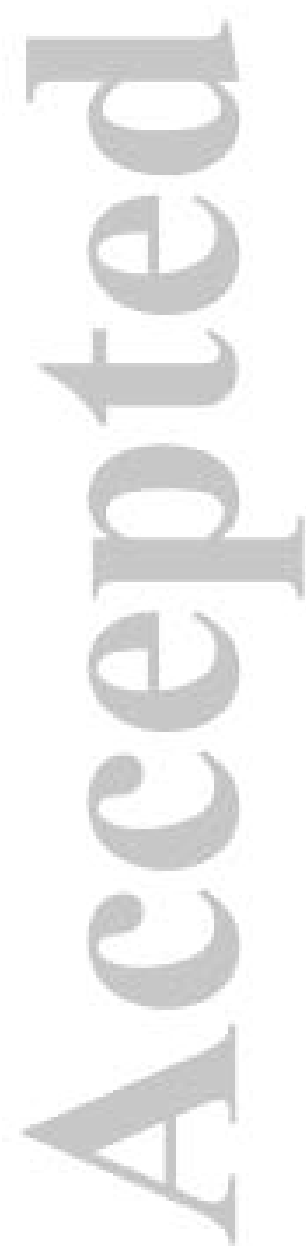
for visualization purposes as a continuous dataset. 
Table 1. Peatland conceptualization in fully-integrated physically-based models. The studies are presented in chronological order and include non-peer-reviewed publications.

\begin{tabular}{|c|c|c|c|c|c|c|c|}
\hline Study & Study objective & Software & $\begin{array}{l}\text { Model } \\
\text { dimen- } \\
\text { sionality }\end{array}$ & $\begin{array}{l}\text { Domain } \\
\text { size }\end{array}$ & Mesh resolution & $\begin{array}{l}\text { Peat } \\
\text { thickness }\end{array}$ & $\begin{array}{l}\text { Peat } \\
\text { hydraulic } \\
\text { properties }\end{array}$ \\
\hline $\begin{array}{l}\text { Smerdon } \\
\text { et al. } \\
(2007)\end{array}$ & $\begin{array}{l}\text { Simulations of lake- } \\
\text { groundwater } \\
\text { interactions } \\
\text { Alberta's } \\
\text { Plains region }\end{array}$ & $\begin{array}{l}\text { Hydro- } \\
\text { GeoSphere }\end{array}$ & $3 \mathrm{D}$ & $\begin{array}{l}3.24 \\
\mathrm{~km}^{2}\end{array}$ & $\begin{array}{l}\text { Horizontal: } 20 \mathrm{~m} \text {; } \\
\text { Vertical: } 0.25 \mathrm{~m} \text { in } \\
\text { the top } 1 \mathrm{~m} \text {; } \\
\text { variable thickness } \\
\text { layers below }\end{array}$ & Uniform * & $\begin{array}{l}\text { Same for the } \\
\text { whole peat }\end{array}$ \\
\hline $\begin{array}{l}\text { Frei et al. } \\
(2010)\end{array}$ & $\begin{array}{l}\text { To improve } \\
\text { understanding of the } \\
\text { effects of micro- } \\
\text { topography on } \\
\text { surface-subsurface } \\
\text { exchange and runoff } \\
\text { generation in a } \\
\text { riparian wetland }\end{array}$ & $\begin{array}{l}\text { HydroGeo- } \\
\text { Sphere }\end{array}$ & $3 \mathrm{D}$ & $\begin{array}{l}200 \mathrm{~m}^{2} \\
(10 \mathrm{~m} \times \\
20 \mathrm{~m} \times 2 \\
\mathrm{~m})\end{array}$ & $\begin{array}{l}\text { Horizontal: } 0.1 \mathrm{~m} \text {; } \\
\text { Vertical: } 0.1 \mathrm{~m}\end{array}$ & $\begin{array}{l}\text { Uniform } \\
(2 \mathrm{~m})\end{array}$ & $\begin{array}{l}\text { Same for the } \\
\text { whole peat }\end{array}$ \\
\hline $\begin{array}{l}\text { Frei et al. } \\
(2012)\end{array}$ & $\begin{array}{l}\text { To investigate how } \\
\text { subsurface flow } \\
\text { patterns induced by } \\
\text { surface micro- } \\
\text { topography affect } \\
\text { subsurface transport } \\
\text { of redox-sensitive } \\
\text { solutes and the } \\
\text { distribution of } \\
\text { biogeochemical } \\
\text { processes }\end{array}$ & $\begin{array}{l}\text { HydroGeo- } \\
\text { Sphere }\end{array}$ & $3 \mathrm{D}$ & $\begin{array}{l}200 \mathrm{~m}^{2} \\
(10 \mathrm{~m} \times \\
20 \mathrm{~m} \times 2 \\
\mathrm{~m})\end{array}$ & $\begin{array}{l}\text { Horizontal: } 0.1 \mathrm{~m} \text {; } \\
\text { Vertical: } 0.1 \mathrm{~m}\end{array}$ & $\begin{array}{l}\text { Uniform } \\
(2 \mathrm{~m})\end{array}$ & $\begin{array}{l}\text { Same for the } \\
\text { whole peat }\end{array}$ \\
\hline $\begin{array}{l}\text { Dureijka } \\
\text { (2013) }\end{array}$ & $\begin{array}{l}\text { To determine the } \\
\text { overall water balance } \\
\text { for a peatland } \\
\text { influenced by lake } \\
\text { level variations and } \\
\text { how the exchange } \\
\text { between peatland and } \\
\text { the adjacent lake is } \\
\text { characterized }\end{array}$ & $\begin{array}{l}\text { HydroGeo- } \\
\text { Sphere }\end{array}$ & $3 \mathrm{D}$ & $\begin{array}{l}5.61 \\
\mathrm{~km}^{2}\end{array}$ & $\begin{array}{l}\text { Horizontal: } \\
\text { unknown, highest } \\
\text { discretization } \\
\text { along drainage } \\
\text { and observation } \\
\text { points; } \\
\text { Vertical: } 0.1 \mathrm{~m} \text { in } \\
\text { the top } 1 \mathrm{~m} \text { and the } \\
\text { rest divided into } 5 \\
\text { equally spaced } \\
\text { layers }\end{array}$ & $\begin{array}{l}\text { Uniform } \\
(6 \mathrm{~m})\end{array}$ & $\begin{array}{l}\text { Variable with } \\
\text { depth }\end{array}$ \\
\hline $\begin{array}{l}\text { Partington } \\
\text { et al. } \\
(2013)\end{array}$ & $\begin{array}{l}\text { To understand and } \\
\text { quantify streamflow } \\
\text { generation processes } \\
\text { at the catchment scale }\end{array}$ & $\begin{array}{l}\text { HydroGeo- } \\
\text { Sphere }\end{array}$ & $3 \mathrm{D}$ & $\begin{array}{l}\text { Riparian } \\
\text { wetland } \\
\text { (Frei } \\
2010 \text {, } \\
2012 \text { ): } \\
210 \mathrm{~m}^{2} \text {; } \\
\text { catchme } \\
\text { nt scale: } \\
4.2 \mathrm{~km}^{2} \\
\end{array}$ & $\begin{array}{l}\text { Horizontal: varies } \\
\text { between } 10-100 \mathrm{~m} \text {; } \\
\text { Vertical: } 0.1 \mathrm{~m} \text { in } \\
\text { the top } 1 \mathrm{~m} \text {, } \\
\text { variable thickness } \\
\text { layers below }\end{array}$ & $\begin{array}{l}\text { Uniform } \\
(1 \mathrm{~m})\end{array}$ & $\begin{array}{l}\text { Hydraulic } \\
\text { conductivity } \\
\text { variable with } \\
\text { depth; other } \\
\text { values kept } \\
\text { constant }\end{array}$ \\
\hline $\begin{array}{l}\text { Frei \& } \\
\text { Fleckenste } \\
\text { in (2014) }\end{array}$ & $\begin{array}{l}\text { To test whether } \\
\text { surface } \\
\text { microtopography can } \\
\text { berrafficiently } \\
\text { replicated by a planar } \\
\text { model superimposed } \\
\text { on rilly } \\
\text { distributed spatially } \\
\text { depression storage } \\
\text { height variations. }\end{array}$ & $\begin{array}{l}\text { HydroGeo- } \\
\text { Sphere }\end{array}$ & $3 \mathrm{D}$ & $\begin{array}{l}200 \mathrm{~m}^{2} \\
(10 \mathrm{mx} \\
20 \mathrm{~m} \times 2 \\
\mathrm{~m})\end{array}$ & $\begin{array}{l}\text { Horizontal: } 0.1 \mathrm{~m} \text {; } \\
\text { Vertical: } 0.1 \mathrm{~m}\end{array}$ & $\begin{array}{l}\text { Uniform } \\
(2 \mathrm{~m})\end{array}$ & $\begin{array}{l}\text { Same for the } \\
\text { whole peat }\end{array}$ \\
\hline $\begin{array}{l}\text { Ala-aho et } \\
\text { al. }(2015 a)\end{array}$ & $\begin{array}{l}\text { To study the temporal } \\
\text { and spatial exchange } \\
\text { between GW and } \\
\text { lakes and streams }\end{array}$ & $\begin{array}{l}\text { HydroGeo- } \\
\text { Sphere }\end{array}$ & $3 \mathrm{D}$ & $250 \mathrm{~km}^{2}$ & $\begin{array}{l}\text { Horizontal; } \\
\text { Vertical: } 0.2 \mathrm{~m} \text {, } \\
0.5 \mathrm{~m}, 0.9 \mathrm{~m}, 1.4 \\
\mathrm{~m} \text { and two }\end{array}$ & $\begin{array}{l}\text { Uniform } \\
\text { (average } \\
\text { peat depth } \\
\text { of } 1.4 \mathrm{~m} \text { ) }\end{array}$ & $\begin{array}{l}\text { Same for the } \\
\text { whole peat }\end{array}$ \\
\hline
\end{tabular}




\begin{tabular}{|c|c|c|c|c|c|c|c|}
\hline & & & & & $\begin{array}{l}\text { proportional } \\
\text { layers }\end{array}$ & & \\
\hline $\begin{array}{l}\text { Jaros } \\
(2015)\end{array}$ & $\begin{array}{l}\text { To examine the } \\
\text { performance of fully- } \\
\text { integrated modeling in } \\
\text { simulating } \\
\text { groundwater- } \\
\text { dependent ecosystems }\end{array}$ & $\begin{array}{l}\text { HydroGeo- } \\
\text { Sphere }\end{array}$ & $3 \mathrm{D}$ & $\begin{array}{l}92.9 \\
\mathrm{~km}^{2}\end{array}$ & 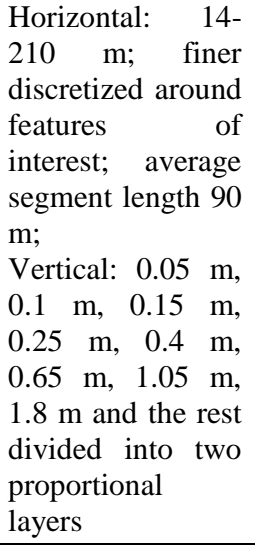 & $\begin{array}{l}\text { Uniform } \\
(1.8 \mathrm{~m})\end{array}$ & $\begin{array}{l}\text { Same for the } \\
\text { whole peat }\end{array}$ \\
\hline $\begin{array}{l}\text { Thompson } \\
\text { et al. } \\
(2015)\end{array}$ & $\begin{array}{l}\text { To evaluate the } \\
\text { hydrological linkages } \\
\text { occurring between } \\
\text { landscape units in a } \\
\text { pond-peatland } \\
\text { complex of Alberta's } \\
\text { Boreal Plains region }\end{array}$ & $\begin{array}{l}\text { HydroGeo- } \\
\text { Sphere }\end{array}$ & $2 \mathrm{D}$ & $\begin{array}{l}\text { Transect } \\
\text { 1: } \sim 450 \\
\mathrm{~m} ; \\
\text { Transect } \\
2: \\
\sim 750 \mathrm{~m}\end{array}$ & $\begin{array}{l}\text { Horizontal: } 1 \mathrm{~m} \text {; } \\
\text { Vertical: } 0.05 \mathrm{~m} \text { to } \\
0.1 \mathrm{~m} \text { in the upper } \\
0.5 \mathrm{~m} \text { and } 0.25 \mathrm{~m} \\
\text { below }\end{array}$ & $\begin{array}{l}\text { Varying } \\
\text { thickness; } \\
\text { accuracy } \\
0.25 \mathrm{~m}\end{array}$ & $\begin{array}{l}\text { All properties } \\
\text { variable with } \\
\text { depth }\end{array}$ \\
\hline $\begin{array}{l}\text { Haahti et } \\
\text { al. (2016) }\end{array}$ & $\begin{array}{l}\text { To examine the } \\
\text { performance of fully- } \\
\text { integrated models to } \\
\text { simulate interactions } \\
\text { between a drainage } \\
\text { network and peatland } \\
\text { moisture conditions }\end{array}$ & FLUSH & $3 \mathrm{D}$ & $\begin{array}{l}0.052 \\
\mathrm{~km}^{2}\end{array}$ & $\begin{array}{l}\text { Horizontal: } 5 \mathrm{~m} \mathrm{x} \\
5 \mathrm{~m} \text {; } \\
\text { Vertical: } 8 \times 0.05 \\
\mathrm{~m}, 6 \times 0.1 \mathrm{~m} \text { and } 4 \\
\mathrm{x} 0.25 \mathrm{~m} \text { from top } \\
\text { to bottom; in total } \\
18 \text { layers }\end{array}$ & $\begin{array}{l}\text { Uniform } \\
(2 \mathrm{~m})\end{array}$ & $\begin{array}{l}\text { Hydraulic } \\
\text { conductivity } \\
\text { and water } \\
\text { retention } \\
\text { curve } \\
\text { parameters } \\
\text { variable with } \\
\text { depth }\end{array}$ \\
\hline $\begin{array}{l}\text { Haahti et } \\
\text { al. (2016) }\end{array}$ & $\begin{array}{l}\text { To understand erosion } \\
\text { mechanisms after } \\
\text { ditch network } \\
\text { maintenance } \\
\text { forested peatlands }\end{array}$ & FLUSH & $3 \mathrm{D}$ & $\begin{array}{l}0.052 \\
\mathrm{~km}^{2}\end{array}$ & $\begin{array}{l}\text { Horizontal: } 5 \mathrm{~m} \mathrm{x} \\
5 \mathrm{~m} \text {; } \\
\text { Vertical: } 8 \times 0.05 \\
\mathrm{~m}, 6 \times 0.1 \mathrm{~m} \text { and } 4 \\
\mathrm{x} 0.25 \mathrm{~m} \text { from top } \\
\text { to bottom; in total } \\
18 \text { layers }\end{array}$ & $\begin{array}{l}\text { Uniform } \\
(2 \mathrm{~m})\end{array}$ & $\begin{array}{l}\text { Hydraulic } \\
\text { conductivity } \\
\text { and water } \\
\text { retention } \\
\text { curve } \\
\text { parameters } \\
\text { variable with } \\
\text { depth }\end{array}$ \\
\hline $\begin{array}{l}\text { Ala-aho et } \\
\text { al. (2017) }\end{array}$ & $\begin{array}{l}\text { To investigate how the } \\
\text { subsurface is involved } \\
\text { in sustaining and } \\
\text { generating streamflow } \\
\text { in a glaciated } \\
\text { headwater catchment; } \\
\text { to define parameter } \\
\text { sensitivities across all } \\
\text { model domains; to } \\
\text { determine what data } \\
\text { are useful to include in } \\
\text { model calibration }\end{array}$ & $\begin{array}{l}\text { HydroGeo- } \\
\text { Sphere }\end{array}$ & $3 \mathrm{D}$ & $3.3 \mathrm{~km} 2$ & $\begin{array}{l}\text { Horizontal: } \\
\text { unknown; highest } \\
\text { discretization } \\
\text { along a stream } \\
\text { with average } \\
\text { segment lengths of } \\
9.6 \mathrm{~m} \text {; } \\
\text { Vertical: } 0.05 \mathrm{~m} \text { in } \\
\text { the top } 0.2 \mathrm{~m}, 0.1 \\
\mathrm{~m} \text { at } 0.2-1 \mathrm{~m} \\
\text { depth, } 0.5 \mathrm{~m} \text { at } 1-2 \\
\mathrm{~m} \text { depth and rest } \\
\text { divided into } 5 \\
\text { equally spaced } \\
\text { layers }\end{array}$ & $\begin{array}{l}\text { Classified } \\
\text { into three } \\
\text { depth } \\
\text { zones: } 0.2 \\
\mathrm{~m}, 1 \mathrm{~m}, 2 \\
\mathrm{~m}\end{array}$ & $\begin{array}{l}\text { Same for the } \\
\text { whole peat } \\
\text { domain }\end{array}$ \\
\hline $\begin{array}{l}\text { Thompson } \\
\text { et al. } \\
(2017)\end{array}$ & $\begin{array}{l}\text { To predict climate } \\
\text { change impacts on } \\
\text { ecosystems in a } \\
\text { catchment of Alberta's } \\
\text { Boreal Plains }\end{array}$ & $\begin{array}{l}\text { HydroGeo- } \\
\text { Sphere }\end{array}$ & $2 \mathrm{D}$ & $\begin{array}{l}\text { Transect } \\
\text { 1: } \sim 450 \\
\mathrm{~m} ; \\
\text { Transect } \\
2: \\
\sim 750 \mathrm{~m}\end{array}$ & $\begin{array}{l}\text { Horizontal: } 1 \mathrm{~m} \text {; } \\
\text { Vertical: } 0.05 \text { to } \\
0.1 \text { in upper } 0.5 \mathrm{~m} \\
\text { and } 0.25 \text { below }\end{array}$ & $\begin{array}{l}\text { Variable; } \\
\text { accuracy } \\
0.25 \mathrm{~m}\end{array}$ & $\begin{array}{l}\text { All properties } \\
\text { variable with } \\
\text { depth }\end{array}$ \\
\hline $\begin{array}{l}\text { Haahti et } \\
\text { al. }(2018)\end{array}$ & $\begin{array}{ll}\text { To evaluate } & \text { sediment } \\
\text { control } & \text { scenarios } \\
\text { practices } & \text { used in }\end{array}$ & FLUSH & $3 \mathrm{D}$ & $\begin{array}{l}0.052 \\
\mathrm{~km}^{2}\end{array}$ & $\begin{array}{l}\text { Horizontal: } 5 \mathrm{~m} \mathrm{x} \\
5 \mathrm{~m} \text {; }\end{array}$ & $\begin{array}{l}\text { Uniform } \\
(2 \mathrm{~m})\end{array}$ & $\begin{array}{l}\text { Hydraulic } \\
\text { conductivity } \\
\text { and water }\end{array}$ \\
\hline
\end{tabular}




\begin{tabular}{|c|c|c|c|c|c|c|c|}
\hline & $\begin{array}{l}\text { forestry peatlands } \\
\text { accompanying ditch } \\
\text { network maintenance } \\
\text { actions }\end{array}$ & & & & $\begin{array}{l}\text { Vertical: } 8 \times 0.05 \\
\mathrm{~m}, 6 \times 0.1 \mathrm{~m} \text { and } 4 \\
\times 0.25 \mathrm{~m} \text { from top } \\
\text { to bottom; in total } \\
18 \text { layers }\end{array}$ & & $\begin{array}{l}\text { retention } \\
\text { curve } \\
\text { parameters } \\
\text { variable with } \\
\text { depth }\end{array}$ \\
\hline $\begin{array}{l}\text { Hwang et } \\
\text { al. (2018) }\end{array}$ & $\begin{array}{l}\text { To investigate why } \\
\text { long-term annual } \\
\text { downstream flow rates } \\
\text { are consistently higher } \\
\text { than upstream rates } \\
\text { under the subhumid } \\
\text { water deficit } \\
\text { conditions in the } \\
\text { Athabasca River } \\
\text { Basin covered by } \\
\text { peatlands and } \\
\text { forestlands }\end{array}$ & $\begin{array}{l}\text { HydroGeoS } \\
\text { phere }\end{array}$ & $3 \mathrm{D}$ & $\begin{array}{l}160,000 \\
\mathrm{~km}^{2}\end{array}$ & $\begin{array}{l}\text { Horizontal: } 3 \mathrm{~km} \\
\text { (refined to } 0.5 \mathrm{~km} \\
\text { close to the main } \\
\text { drainage features) } \\
\text { Vertical: varying } \\
\text { thickness; } \\
\text { thickness of the } \\
\text { first top layers less } \\
\text { than } 0.5 \mathrm{~m} \text {, third } \\
\text { layer } 1.5 \mathrm{n} \mathrm{and} \\
\text { fourth layer } 1 \mathrm{~m} \text {; } \\
\text { other layers depth } \\
\text { unknown }\end{array}$ & $\begin{array}{l}\text { Varying } \\
\text { thickness } \\
\text { represente } \\
\text { d by } 4 \\
\text { layers of } \\
\text { variable } \\
\text { depth }\end{array}$ & $\begin{array}{l}\text { Two layers of } \\
\text { dual-porosity } \\
\text { model: highly } \\
\text { conductive } \\
\text { layer in top } 0.5 \\
\text { m and the less } \\
\text { conductive } \\
\text { layer below } \\
0.5 \mathrm{~m}\end{array}$ \\
\hline $\begin{array}{l}\text { Jaros et al. } \\
\text { (2019) }\end{array}$ & $\begin{array}{l}\text { To investigate the } \\
\text { effect of } \\
\text { parameterization with } \\
\text { global sensitivity } \\
\text { analysis on } \\
\text { groundwater-surface } \\
\text { water interactions in a } \\
\text { boreal esker-aapa mire } \\
\text { system }\end{array}$ & $\begin{array}{l}\text { HydroGeo- } \\
\text { Sphere }\end{array}$ & $3 \mathrm{D}$ & $107 \mathrm{~km}^{2}$ & $\begin{array}{l}\text { Horizontal: } \\
\text { unknown; } \\
\text { Vertical: } 0.05 \mathrm{~m} \text {, } \\
0.1 \mathrm{~m}, 0.25 \mathrm{~m} \text {, } \\
\text { variable depth of } \\
\text { the interface } \\
\text { between high K } \\
\text { and low K layers, } \\
1.35 \mathrm{~m} \text { and rest } \\
\text { divided into two } \\
\text { proportional } \\
\text { layers }\end{array}$ & $\begin{array}{l}\text { Uniform } \\
\text { (variable } \\
\text { depth of } \\
\text { the } \\
\text { interface } \\
\text { between } \\
\text { high K } \\
\text { and low K } \\
\text { layers); } \\
\text { bottom at } \\
1.35 \mathrm{~m}\end{array}$ & $\begin{array}{l}\text { Two layers: } \\
\text { highly } \\
\text { conductive } \\
\text { layer and less } \\
\text { conductive } \\
\text { layer }\end{array}$ \\
\hline
\end{tabular}

*Information not implicitly stated in the manuscript 
Table 2. Summary of the conceptual models (CMs) investigated in this study. Modified conditions with respect to the reference model (1a) are reported for each case.

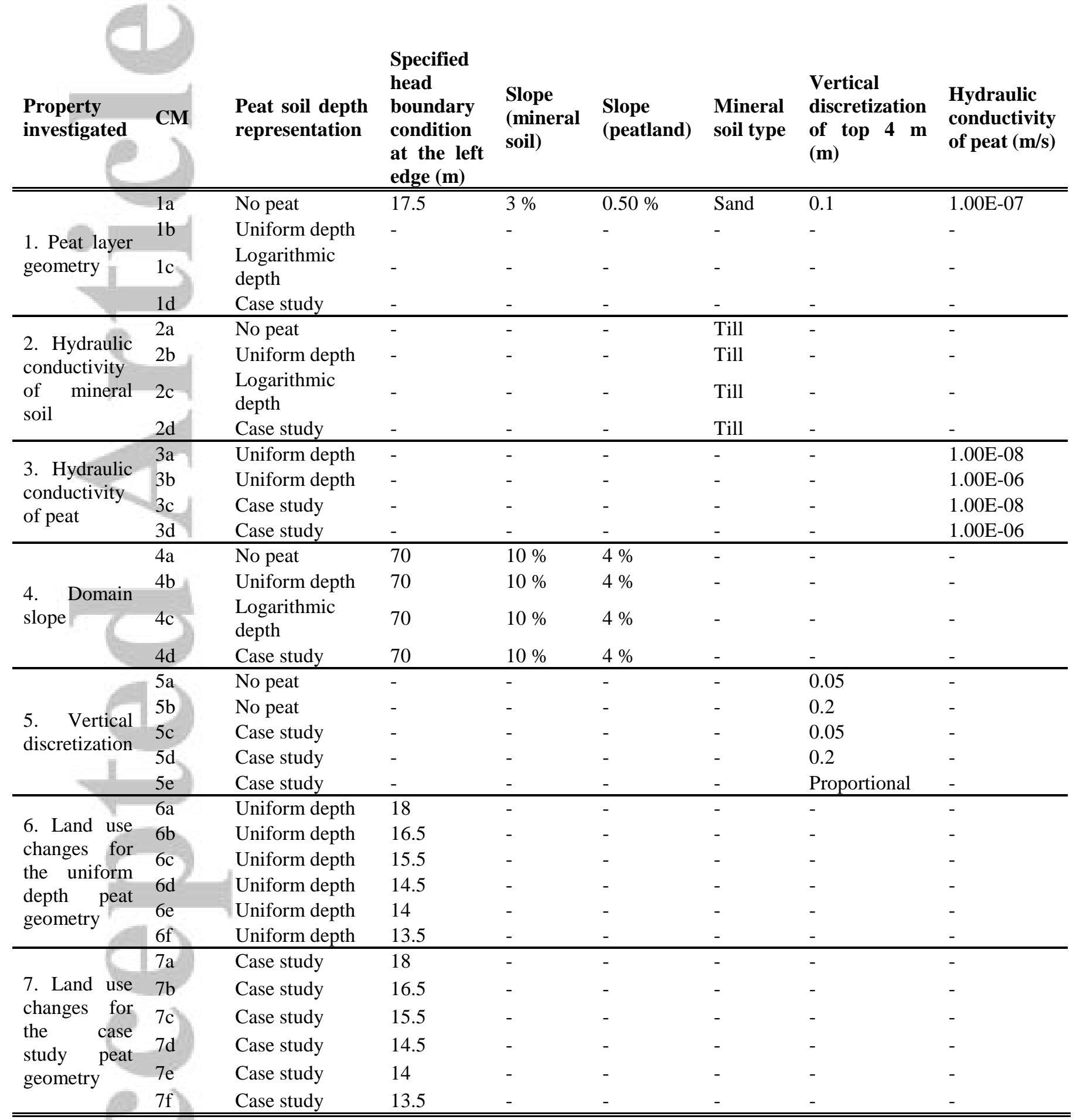

'-' indicates no change in the value in comparison to the reference model. 
Table 3. Effect of boundary conditions on groundwater (GW) level and effective GW-surface water (SW) exchange fluxes.

\begin{tabular}{|c|c|c|c|c|c|c|}
\hline $\begin{array}{l}\text { Property } \\
\text { investigated }\end{array}$ & $\begin{array}{l}\text { Conceptual } \\
\text { model (CM) }\end{array}$ & $\begin{array}{l}\text { Boundary } \\
\text { conditions } \\
\text { at the } \\
\text { right edge } \\
\text { (m) } \\
\end{array}$ & $\begin{array}{l}\text { Average } \\
\text { depth to } \\
\text { groundwater } \\
\text { in peatland } \\
(\mathrm{m}) \\
\end{array}$ & $\begin{array}{l}\text { Max. depth to } \\
\text { groundwater } \\
\text { in peatland } \\
\text { (m) }\end{array}$ & $\begin{array}{l}\text { Effective GW- } \\
\text { SW exchange } \\
\text { flux in peatland } \\
\left(\mathrm{m}^{3} / \mathrm{s}\right)\end{array}$ & $\begin{array}{l}\text { GW-SW } \\
\text { exchange flux } \\
(\% \text { of the } \\
\text { reference } \\
\text { model }) \\
\end{array}$ \\
\hline \multirow{7}{*}{$\begin{array}{l}\text { Land use } \\
\text { changes for } \\
\text { uniform } \\
\text { depth peat } \\
\text { soil layer } \\
\text { geometry }\end{array}$} & $6 a$ & 18 & 0 & 0.00 & $8.50 \mathrm{E}-07$ & $115.85 \%$ \\
\hline & Reference $1 b$ & 17.5 & 0 & 0.00 & 7.34E-07 & $100.00 \%$ \\
\hline & $6 b$ & 16.5 & 0 & 0.00 & $5.12 \mathrm{E}-07$ & $69.83 \%$ \\
\hline & $6 c$ & 15.5 & 0 & 0.00 & $3.06 \mathrm{E}-07$ & $41.71 \%$ \\
\hline & $6 d$ & 14.5 & 0 & 0.02 & $1.16 \mathrm{E}-07$ & $15.75 \%$ \\
\hline & $6 e$ & 14 & 0.02 & 0.13 & $3.06 \mathrm{E}-08$ & $4.16 \%$ \\
\hline & $6 f$ & 13.5 & 0.16 & 0.4362 & $-1.77 \mathrm{E}-15$ & $0.00 \%$ \\
\hline \multirow{7}{*}{$\begin{array}{l}\text { Land use } \\
\text { changes for } \\
\text { uniform } \\
\text { depth peat } \\
\text { soil layer } \\
\text { geometry }\end{array}$} & $7 \mathrm{a}$ & 18 & 0 & 0 & $9.61 \mathrm{E}-07$ & $115.78 \%$ \\
\hline & Reference 1d & 17.5 & 0 & 0 & $8.30 \mathrm{E}-07$ & $100.00 \%$ \\
\hline & $7 b$ & 16.5 & 0 & 0 & 5.81E-07 & $69.97 \%$ \\
\hline & $7 c$ & 15.5 & 0 & 0.004 & $3.48 \mathrm{E}-07$ & $42.00 \%$ \\
\hline & $7 d$ & 14.5 & 0.0002 & 0.03 & $1.28 \mathrm{E}-07$ & $15.45 \%$ \\
\hline & $7 \mathrm{e}$ & 14 & 0.014 & 0.16 & $1.67 \mathrm{E}-08$ & $2.01 \%$ \\
\hline & $7 f$ & 13.5 & 0.134 & 0.43 & $-1.43 \mathrm{E}-15$ & $0.00 \%$ \\
\hline
\end{tabular}

